\title{
Building a field- and model-based climatology of local water and energy cycles in the cultivated Sahel - annual budgets and seasonality
}

\author{
C. Velluet $^{1,2}$, J. Demarty ${ }^{2}$, B. Cappelaere ${ }^{2}$, I. Braud ${ }^{3}$, H. B.-A. Issoufou ${ }^{4}$, N. Boulain ${ }^{2}$, D. Ramier ${ }^{2,5}$, I. Mainassara ${ }^{6,7}$, \\ G. Charvet ${ }^{2}$, M. Boucher ${ }^{2,8}$, J.-P. Chazarin ${ }^{2}$, M. Ö̈ ${ }^{2}$, H. Yahou ${ }^{4,7}$, B. Maidaji ${ }^{4,6}$, F. Arpin-Pont ${ }^{9}$, N. Benarrosh ${ }^{2}$, \\ A. Mahamane ${ }^{4}$, Y. Nazoumou ${ }^{7}$, G. Favreau ${ }^{2}$, and J. Seghieri ${ }^{2}$ \\ ${ }^{1}$ Université Montpellier 2, UMR HSM (CNRS/IRD/UM1/UM2), Montpellier, France \\ ${ }^{2}$ IRD, UMR HSM (CNRS/IRD/UM1/UM2), Montpellier, France \\ ${ }^{3}$ IRSTEA, Unit HHLY, Lyon, France \\ ${ }^{4}$ Université de Maradi, Biology Department, Maradi, Niger \\ ${ }^{5}$ Cerema, DTer IDF, Trappes-en-Yvelines, France \\ ${ }^{6}$ IRD, UMR HSM (CNRS/IRD/UM1/UM2), Niamey, Niger \\ ${ }^{7}$ Université Abdou Moumouni, Geology Department, Niamey, Niger \\ ${ }^{8}$ IRD, LTHE, Grenoble, France \\ ${ }^{9}$ CNRS, UMR HSM (CNRS/IRD/UM1/UM2), Montpellier, France
}

Correspondence to: B. Cappelaere (bernard.cappelaere@ird.fr)

Received: 9 March 2014 - Published in Hydrol. Earth Syst. Sci. Discuss.: 13 May 2014

Revised: 10 October 2014 - Accepted: 13 October 2014 - Published: 10 December 2014

\begin{abstract}
In the sub-Saharan Sahel, energy and water cycling at the land surface is pivotal for the regional climate, water resources and land productivity, yet it is still very poorly documented. As a step towards a comprehensive climatological description of surface fluxes in this area, this study provides estimates of long-term average annual budgets and seasonal cycles for two main land use types of the cultivated Sahelian belt: rainfed millet crop and fallow bush. These estimates build on the combination of a 7-year field data set from two typical plots in southwestern Niger with detailed physically based soil-plant-atmosphere modeling, yielding a continuous, comprehensive set of water and energy flux and storage variables over this multiyear period. In the present case in particular, blending field data with mechanistic modeling makes the best use of available data and knowledge for the construction of the multivariate time series. Rather than using the model only to gap-fill observations into a composite series, model-data integration is generalized homogeneously over time by generating the whole series with the entire data-constrained model simulation. Climatological averages of all water and energy variables, with
\end{abstract}

associated sampling uncertainty, are derived at annual to subseasonal scales from the time series produced. Similarities and differences in the two ecosystem behaviors are highlighted. Mean annual evapotranspiration is found to represent $\sim 82-85 \%$ of rainfall for both systems, but with different soil evaporation/plant transpiration partitioning and different seasonal distribution. The remainder consists entirely of runoff for the fallow, whereas drainage and runoff stand in a $40-60 \%$ proportion for the millet field. These results should provide a robust reference for the surface energy- and water-related studies needed in this region. Their significance and the benefits they gain from the innovative data-model integration approach are thoroughly discussed. The model developed in this context has the potential for reliable simulations outside the reported conditions, including changing climate and land cover. 


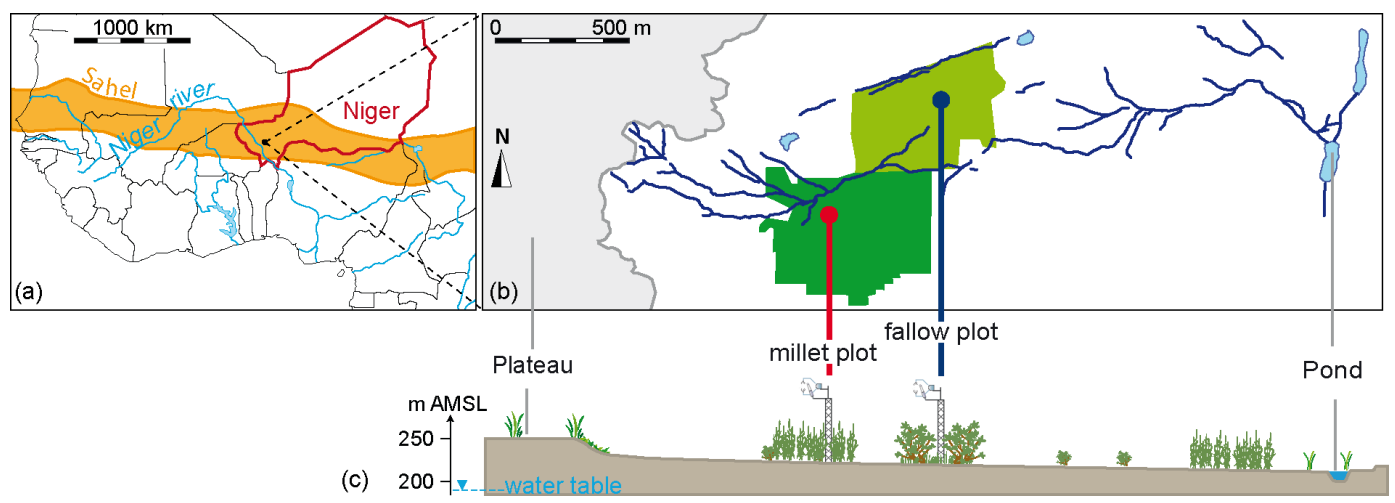

Figure 1. Situation of study plots: (a) location in Sahelian southwestern Niger, West Africa, (b) planar and (c) cross-sectional views of Wankama hillslope with plot locations (modified after Ramier et al., 2009; vegetation and towers not sketched to scale in c).

\section{Introduction}

In Africa, counterintuitive water cycle dynamics (Favreau et al., 2009; Descroix et al., 2013) and prospects of increased water stress (Boko et al., 2007) or decreasing yields of rainfed agriculture (Schlenker and Lobell, 2010) challenge our ability to provide reliable projections of these key resources, especially in the densely populated, semiarid Sahel (rainfall $\sim 300-700 \mathrm{~mm} \mathrm{yr}^{-1}$; Fig. 1a). Surface-atmosphere interactions are critical processes for the water cycle in this region. Strong evaporation recycles much of the rainfall to the atmosphere locally (Boulain et al., 2009b), and the surface feedback as vapor and radiative or turbulent energy plays a major role in atmosphere dynamics (Koster et al., 2004; Wolters et al., 2010; Taylor et al., 2011, 2012). Hence, meteorology, rainfall, and primary production all strongly depend on processes at the ground-atmosphere interface (GAI), as does recharge of the many ponds and of the underlying aquifer (Cappelaere et al., 2009; Favreau et al., 2009; Massuel et al., 2011).

Despite the importance of these surface processes, quantitative knowledge of surface exchanges and groundatmosphere interactions is still very limited in sub-Saharan Africa. Their distribution in space and time is all the more poorly documented. In the Sahelian domain of the West African monsoon, scarce field observations have generally covered only short periods of time - typically a few days to a few weeks - at a few sites (e.g., Lloyd et al., 1997; Ezzahar et al., 2009; Timouk et al., 2009). Few studies have covered a complete seasonal cycle (Wallace et al., 1991; Miller et al., 2009; Ramier et al., 2009). To our knowledge, none have been based on a period of several years that is needed to capture the strong interannual variability of Sahelian rainfall. Current adverse public security conditions throughout the Sahelian belt leave little hope that the complex type of instrumentation required (eddy covariance, scintillometry) could be significantly densified in the near future. In this context, remote sensing estimations are particularly promising for this region. However, methods are still in development, and require context-specific field evaluation and calibration (e.g., Tanguy et al., 2012; Verhoef et al., 2012; Marshall et al., 2013). This is also true for model-derived estimates, as the ability of the current generation of land surface models (LSMs) to correctly reproduce dominant land processes in Africa is still largely in question (Boone et al., 2009a). Evaluating and improving the capabilities of general-purpose LSMs for this large continental region requires substantial reliable documentation of surface energy and water cycles at different space- and timescales (Boone et al., 2009b).

When available, field estimates of surface fluxes are undoubtedly an invaluable asset. Nearly all components (radiative, conductive, turbulent) of the surface energy cycle are now more or less readily accessible to field estimation, even though this involves rather complex techniques and inhomogeneous representative scales. However, these data are associated with significant uncertainty, particularly for turbulent fluxes of sensible and latent heat. This uncertainty arises from a variety of sources such as instrumental error, departure of field conditions from underlying theory, or processing pitfalls (Foken et al., 2006; Aubinet et al., 2012). The general lack of energy balance closure that results from these estimation problems typically ranges between 10 and $35 \%$ of the available energy (Foken, 2008). Its assignment to the various possible sources is still a matter of debate (Aubinet et al., 2012). When estimation becomes unreliable, the corresponding data must be discarded. Added to the recurrent interruption of sensitive equipment in harsh field conditions (dust, temperature, wind), this generally leads to substantial gap rates in the derived time series. For the surface water cycle, a number of components can hardly be field-measured precisely and continuously on a routine basis, e.g., overland runoff, vertical drainage, and lateral subsurface flow, or partitioning of evapotranspiration into direct soil evaporation and canopy transpiration. For all these reasons - sparse data sets, unobserved components, and uncertain data with conservation biases - it is not feasible to estimate complete and re- 
liable water and energy balances at various timescales from field observations only, and some sort of modeling is thus necessary. Combining as many field observations as possible with physics-driven models, which integrate available knowledge of the main local water and energy cycling processes, appears to be the most reliable way to make robust quantitative estimates of surface-atmosphere exchanges, particularly in this region.

In this context, the purpose of this study is to propose for the first time to our knowledge - a description that can be representative, in a climatological sense, of water and energy cycles for two dominant land cover types in the cultivated Sahel, namely rainfed millet crop and fallow bush. First-order dynamics at annual to sub-seasonal scales are analyzed here, through estimation of long-term means. A reliable climatology is useful as a powerful reference for a variety of purposes, including extracting the most significant features in system dynamics, deriving anomalies, analyzing processes and understanding system behavior, making robust comparisons between systems or across different bioclimatic settings (globally or regionally as expected from the AMMA$\mathrm{CATCH}^{1}$ network in West Africa; Lebel et al., 2009), or evaluating and improving land surface models and remote sensing algorithms efficiently (e.g., bias detection and characterization).

This climatological description is based on the production and analysis of a multivariate series covering an unprecedented full 7-year-long period for two plots in Niger (Velluet, 2014). This continuous series was obtained by combining a unique field data set over that period (Boulain et al., 2009a; Cappelaere et al., 2009; Ramier et al., 2009) with the physically based SiSPAT (Simple Soil-Plant-Atmosphere Transfers) model (Braud et al., 1995). The study area is located in the so-called central Sahel region, which is considered the most representative of the West African monsoon rainfall regime (Lebel and Ali, 2009). Available data include local rainfall and meteorology, vegetation phenology, all surface energy cycle components, and soil moisture and temperature profiles. The SiSPAT model solves the 1-D vertical equations for coupled diffusive transfers of water and heat in a heterogeneous soil, coupled with surface and plant exchanges with the atmosphere. It has been shown (Demarty et al., 2004; Shin et al., 2012) that even in the general heterogeneous, layered case, this type of soil water model can be reliably inverted for hydrodynamic properties from soil moisture observations when the profile is predominantly draining (no underlying moisture source), which is the case in nearly all of this region. SiSPAT has already been tested successfully over a short period in this environment (Braud et al., 1997; Braud, 1998). Other GAI studies, either data-based (e.g., Miller et al., 2009; Ramier et al., 2009; Lohou et al., 2014) or model-

\footnotetext{
${ }^{1}$ African Monsoon Multidisciplinary Analyses - Coupling Tropical Atmosphere and Hydrological Cycle; http://www.amma-catch. org.
}

based (e.g., Daamen, 1997; Pellarin et al., 2009; Saux-Picart et al., 2009a, b), were carried out in the study area. However, as mentioned earlier for the whole subregion, they were all limited to sub-seasonal periods or at most to one particular year. The models used were generally less detailed than in this study, with a more exploratory perspective. Deriving a reference climatology as done here requires a long-enough, complete, and reliable series. This required continuous multivariate series is provided by the strongly data-constrained 7-year model simulation, which is used in its entirety rather than only for gap-filling observations into a composite series. As the paper shows, the series allows capturing statistical population averages for the variables investigated, while minimizing the effect of possible decadal non-stationarities of the monsoon (Lebel and Ali, 2009) or of land management. As it carries the most robust features in the dynamics, analysis of mean system behavior enables a powerful comparison of the two investigated systems. These results should contribute a substantial step to documenting the dynamics of surface fluxes in the Sahel.

After a brief description of sites, data, model, and overall methodology (Sect. 2), results are presented for the climatology of a synthetic average year from annual to sub-seasonal timescales (Sect. 3). The significance of these results - as induced in particular by the study methodology - as well as information inferred on key processes are discussed in Sect. 4. As they play a key part in the methodology, implementation and evaluation steps for model-data integration (parameter estimation, model validation) are detailed separately in Appendices $\mathrm{A}$ and $\mathrm{B}$, for better overall readability.

\section{Materials and methods}

Equations of water and energy conservation are written as

$P=R+D+\mathrm{Ev}+\mathrm{Tr}+\mathrm{d} S / \mathrm{d} t$

$\mathrm{SW}_{\text {in }}=\mathrm{SW}_{\text {out }}+\mathrm{LW}_{\text {net }}+R_{\mathrm{n}}$ with : $R_{\mathrm{n}}=G+H+\mathrm{LE}$

and $: \mathrm{LW}_{\text {net }}=\mathrm{LW}_{\text {out }}-\mathrm{LW}_{\text {in }} ; \mathrm{LE}=\lambda \cdot \mathrm{ET} ; \mathrm{ET}=\mathrm{Ev}+\mathrm{Tr}$,

where $P$ is precipitation, $R$ runoff, $D$ drainage below soil column, Ev direct soil evaporation, Tr plant transpiration, ET evapotranspiration, $\mathrm{d} S / \mathrm{d} t$ water storage variation in soil column, $R_{\mathrm{n}}$ net radiation, $\mathrm{SW}$ in global radiation, $\mathrm{SW}_{\text {out }}$ reflected solar radiation, $\mathrm{LW}_{\text {net }}$ net long-wave radiation, $\mathrm{LW}_{\text {in }}$ and $\mathrm{LW}_{\text {out }}$ down- and upwelling long-wave radiation, $G$ ground heat flux, $H$ sensible heat flux, LE latent heat flux, and $\lambda$ latent heat of vaporization (units used hereafter are millimeter per unit time for $P, R, D, \mathrm{Ev}$, Tr, ET and $\mathrm{d} S / \mathrm{d} t, \mathrm{~W} \mathrm{~m}^{-2}$ for $\mathrm{SW}_{\text {in }}, \mathrm{SW}_{\text {out }}, \mathrm{LW}_{\text {in }}, \mathrm{LW}_{\text {out }}, \mathrm{LW}_{\text {net }}, R_{\mathrm{n}}, G, H$ and LE, and $\mathrm{kJ} \mathrm{m}^{-3}$ for $\lambda$ ).

\subsection{Study area}

The study area is located $\sim 60 \mathrm{~km}$ east of Niamey, at $13.6^{\circ} \mathrm{N}$, $2.6^{\circ} \mathrm{E}$ in the southwest of the Republic of Niger (Fig. 1). It 
consists of two plots of around 15 ha each, located $\sim 0.5 \mathrm{~km}$ apart on the slope of the $2 \mathrm{~km}^{2}$ Wankama catchment, in the AMMA-CATCH observatory (Cappelaere et al., 2009; Lebel et al., 2009). The plots consist of a millet field - millet is the single most important staple crop in the whole Sahel belt - and of a fallow field which is an integral part of the traditional cropping system (views of plots in Cappelaere et al., 2009; Boulain et al., 2009a; Velluet, 2014). These are now by far the two main land use types in southwestern Niger (Leblanc et al., 2008; Descroix et al., 2009), as in much of the cultivated Sahel (van Vliet et al., 2013). The climate of the area is tropical semiarid, with average rainfall of $\sim 500 \mathrm{~mm} \mathrm{yr}^{-1}$ and mean temperature of $\sim 30^{\circ} \mathrm{C}$. It is typical of the West African monsoon regime, with a long dry season of $\sim 6$ months (November-April) with practically no rain, and a wet season with 30-50 convective storms concentrated mostly from June through September. Figure 2 shows this strong meteorological seasonality at Wankama, especially for rainfall, humidity, and wind, and to a lesser extent temperature. Soils are sandy, weakly structured, poor in nutrients, and prone to surface crusting, with an unsaturated depth of several tens of meters (Massuel et al., 2006). Pearl millet (Pennisetum glaucum) is grown using traditional techniques, relying on rainfall and animal manuring with no irrigation and very little or no chemical fertilization. Sparse shrubs of Guiera senegalensis are left to grow in the crop fields and cut yearly just before the growing season (AprilMay). Before sowing, weeds are removed by shallow tilling with a hand hoe. After the first $5-10 \mathrm{~mm}$ of rainfall, traditional non-photosensitive varieties of millet are sown in pockets with a $\sim 1 \mathrm{~m}$ spacing. Depending on subsequent rain or drought, it may need to be re-sown several times before plants can actually develop. Millet is harvested in late September or October, after the end of the rainy season. Shrubs are allowed to grow again from any remaining soil moisture in the late monsoon, until the end of the dry season. The fallow vegetation typically consists of a shrub layer dominated by Guiera senegalensis $\left(<10^{3}\right.$ individuals $\mathrm{ha}^{-1}$, $\sim 2 \mathrm{~m} \mathrm{high}$ ) and of a grass layer made of annual $\mathrm{C} 3$ and $\mathrm{C} 4$ species in variable composition, interspersed with bare soil patches (Boulain et al., 2009a). Traditional crop-fallow cycles used to alternate 10-20 years of fallow with 3-5 years of cropping, but with the acute need for food production this ratio is now almost reversed.

\subsection{Field data and study period}

At the start of the 2005 monsoon, the two plots were equipped with an identical data acquisition setup for continuous recording of (i) meteorology: rainfall, air pressure, temperature and humidity, wind speed and direction, fourcomponent radiation; (ii) high-frequency eddy covariance for sensible and latent heat flux estimation: 3-D wind, temperature, and vapor concentration (carbon flux also monitored but not used in this study); (iii) soil variables: shallow
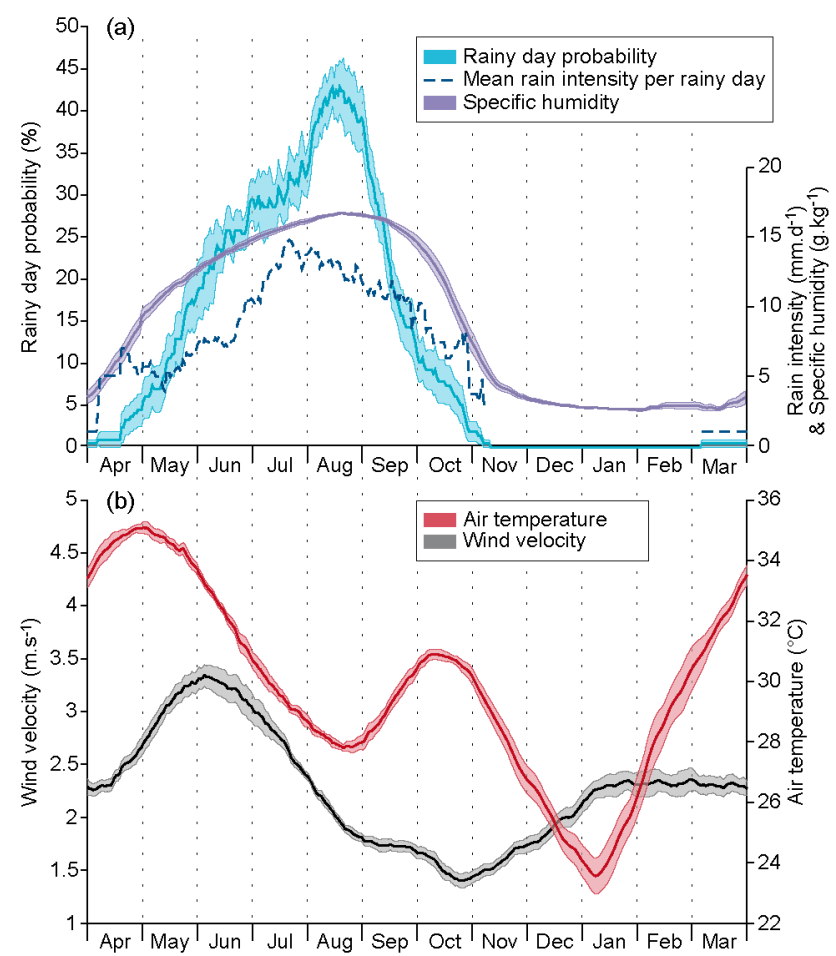

Figure 2. Mean seasonal courses of meteorological variables in Wankama catchment: (a) probability and mean rain intensity of a rainy day and specific humidity; (b) air temperature and $3 \mathrm{~m}$ wind velocity. Values are 30-day running averages for 2005-2012, from instruments described in Table 1. Light-colored intervals represent a variation of \pm 1 standard estimation error.

ground heat flux, $2.5 \mathrm{~m}$ deep temperature and moisture profiles. Details of this setup are given in Table 1. The millet plot was turned to cultivation just before instrumentation began in 2005, while the fallow field had not been cropped since the early 2000s. In both plots, land use remained unchanged throughout the 7-year study period (May 2005-April 2012). Soil texture and bulk density were analyzed from samples taken along several $2.5 \mathrm{~m}$ deep profiles at different dates over the period to calibrate soil moisture sensors for volumetric water content. Consistent particle size distributions of $\sim 84-92 \%$ sand and $\sim 5-13 \%$ clay were found in all profiles. Porosity was estimated from bulk density, in the range of $0.32-0.36 \mathrm{~m}^{3} \mathrm{~m}^{-3}$.

For the practical and theoretical reasons mentioned earlier (e.g., equipment failure, temporarily unsuitable conditions), the data series include gaps of variable lengths (10-35\% missing data). Meteorological variables, needed for model forcing, were gap-filled by substituting the closest available data from similar instruments deployed over the Wankama catchment (Cappelaere et al., 2009). Eddy covariance data were processed into half-hourly turbulent fluxes, using EdiRe software (R. Clement, University of Edinburgh) and CarboEurope recommendations (Mauder and Foken, 2004), as described in Ramier et al. (2009). Energy balance closure ob- 
Table 1. Description of permanent GAI-recording stations in the Wankama fallow and millet plots.

\begin{tabular}{|c|c|c|c|}
\hline Instrument & Measurements & Height or depth & Frequency \\
\hline \multicolumn{4}{|c|}{ Above ground } \\
\hline $\begin{array}{l}\text { Campbell CSAT-3 sonic } \\
\text { anemometer (Campbell Scientific, } \\
\text { Inc, Logan, USA) }\end{array}$ & $\begin{array}{l}\text { 3-D wind speed and direction } \\
\text { Sonic air temperature }\end{array}$ & $5 \mathrm{~m}$ & $20 \mathrm{~Hz}$ \\
\hline $\begin{array}{l}\text { LI-COR LI-7500 infrared gas } \\
\text { analyzer (LI-COR Biosciences, } \\
\text { Lincoln, USA) }\end{array}$ & $\begin{array}{l}\mathrm{CO}_{2} \text { and } \mathrm{H}_{2} \mathrm{O} \text { concentrations } \\
\text { Air pressure }\end{array}$ & $5 \mathrm{~m}$ & $20 \mathrm{~Hz}$ \\
\hline $\begin{array}{l}\text { Kipp \& Zonen CNR1 radiometer } \\
\text { (Kipp \& Zonen, Delft, the } \\
\text { Netherlands) }\end{array}$ & $\begin{array}{l}\text { Shortwave }(0.3-2.8 \mu \mathrm{m}) \text { and } \\
\text { long-wave }(5-50 \mu \mathrm{m}) \text { incoming and } \\
\text { outgoing radiation }\end{array}$ & $\begin{array}{l}3.5 \mathrm{~m} \text { (fallow) } \\
2.5 \mathrm{~m} \text { (millet) }\end{array}$ & $1 \mathrm{~min}$ \\
\hline $\begin{array}{l}\text { Wind monitor RM103 } \\
\text { (Young, Traverse City, USA) }\end{array}$ & 2-D wind speed and direction & $3 \mathrm{~m}$ & $1 \mathrm{~min}$ \\
\hline $\begin{array}{l}\text { Vaisala HMP45C (Vaisala Oyj, } \\
\text { Helsinki, Finland) }\end{array}$ & $\begin{array}{l}\text { Air temperature and relative } \\
\text { humidity }\end{array}$ & $3 \mathrm{~m}$ & $1 \mathrm{~min}$ \\
\hline \multicolumn{4}{|c|}{ Soil measurements } \\
\hline $\begin{array}{l}\text { Campbell CS616 water content } \\
\text { reflectometers }(6)\end{array}$ & Soil volumetric water content & $-0.1,-0.5,-1.0,-1.5,-2.0,-2.5 \mathrm{~m}$ & $1 \mathrm{~min}$ \\
\hline Campbell T108 temperature probes (6) & Soil temperature & $-0.1,-0.5,-1.0,-1.5,-2.0,-2.5 \mathrm{~m}$ & $1 \mathrm{~min}$ \\
\hline $\begin{array}{l}\text { Hukseflux HFP01SC heat flux } \\
\text { plates (3, averaged) (Hukseflux, } \\
\text { Delft, the Netherlands) }\end{array}$ & Surface soil heat flux & $-0.05 \mathrm{~m}$ & $1 \mathrm{~min}$ \\
\hline
\end{tabular}

tained with the different measured and estimated flux components is typical of what is commonly obtained with this type of instrumentation (Ramier et al., 2009). Extracts from these eddy covariance data have been extensively analyzed in various - local, regional, methodological - studies (e.g., Boulain et al., 2009a; Merbold et al., 2009; Ramier et al., 2009; Tanguy et al., 2012; Verhoef et al., 2012; Marshall et al., 2013; Sjöstrom et al., 2011, 2013; Lohou et al., 2014).

A field survey of vegetation phenology was conducted at both plots every 1 or 2 weeks from June through December of all 7 years (Boulain et al., 2009a). Of particular interest for this study are the seasonal courses of vegetation height and leaf area index (LAI). Height was sampled from 15-30 individuals per plot and date. LAI was derived from hemispherical photographs, following the protocol prescribed by the VALERI project (http://www.avignon.inra.fr/ valeri). They were acquired at 13 locations in a $20 \times 20 \mathrm{~m}$ square in each plot, using a Canon EOS 500 numerical camera with a Sigma-8mm-F4 fisheye lens, and were processed with the Can-Eye software (Weiss et al., 2004). To obtain continuous daily series over the study period (Fig. 3), LAI was interpolated between surveys and extrapolated outside surveying periods based on a regression on surface albedo, as recorded by the shortwave radiometers.

\subsection{Model principles}

The SiSPAT model (Braud et al., 1995; Braud, 2000; Demarty et al., 2002) was chosen for its ability to simulate the coupled heat and water exchanges through the soil-plantatmosphere continuum on physical bases. Model overview diagrams are provided by Fig. 1 in Demarty et al. (2004) and Fig. 6.2 in Velluet (2014). As a SVAT (soil-vegetationatmosphere transfer) column model, it is forced at a reference level with observed meteorology (rainfall, wind speed, air temperature and humidity, atmospheric pressure, incoming short- and long-wave radiation). Two energy budgets, one for the vegetation canopy and one for the soil surface, are solved concurrently and continuously for surface-atmosphere exchanges over the diurnal cycle, with temperature and humidity at the soil surface, at the leaf surface, and at the canopy level of the atmosphere as state variables. Leaf area is prescribed as time-variable LAI, and also conditions a rainfall interception reservoir. Turbulent fluxes are expressed using a classical electrical analogy in this two-layer system, based on the computation of a bulk stomatal resistance and of three aerodynamic resistances. The bulk stomatal resistance, representing the plant physiological response to climatic and environmental conditions, is modeled in terms of incoming global radiation, vapor pressure deficit, and leaf water potential (Jarvis, 1976). The three aerodynamic resistances are determined using the Shuttleworth and Wallace (1985) wind 
profile parameterization inside and above the canopy. Radiation transfers in the short- and long-wave bands account for the two-layer formalism with shielding and multiple reflection effects (Taconet et al., 1986).

A major strength of the model is its mechanistic representation of soil thermal and hydraulic dynamics, accomplished by solving the coupled differential equations of heat and mass transfer, including vapor phase. This allows in particular to account for strong heterogeneity in the soil profile, e.g., the common presence of a surface crust in this environment or several soil horizons with contrasted thermal and hydraulic conduction and retention properties. Different parameterizations of the hydraulic conductivity and retention curves are possible. Each horizon is discretized for a numerical solution of the dynamic and continuity equations, with variable node density in relation to magnitude of state variable gradients (e.g., higher near the surface or horizon boundaries). Water is extracted by plants based on a prescribed, constant or dynamic root density profile, assuming no plant storage (Federer, 1979; Milly, 1982). The aboveand below-surface model components are coupled through soil surface temperature and humidity, leaf water potential, and conservation of energy and mass at the soil and plant surfaces. A lower boundary condition needs to be assigned for both the heat and mass transfer equations at the bottom of the simulated soil column. Various boundary condition types, including Dirichlet and Neumann types, are proposed (Braud, 2000). The model is forced with meteorological data at a sub-hourly timestep to capture the diurnal cycle, and the data are linearly interpolated at the computational timestep. The timestep is adjusted automatically according to soil water pressure and temperature gradients. This enables accurate representation of process dynamics (e.g., when sharp variations occur during rain events) as well as satisfaction of numerical convergence and stability criteria.

The SiSPAT model has been previously applied to Sahelian sites near the study area (Braud et al., 1997; Braud, 1998), for relatively short simulation periods, but with encouraging results as to the model's ability to reproduce the Sahelian GAI behavior. It has also been used successfully in a variety of other complex, physics-oriented applications, such as isotopic tracing (e.g., Rothfuss et al., 2012) and remotesensing simulations (e.g., Demarty et al., 2005).

\subsection{Methodology}

The SiSPAT model is forced for the fallow and millet plots with their 7-year (1 May 2005-30 April 2012) time series of half-hourly meteorological variables and daily LAI. A $4 \mathrm{~m}$ deep soil domain is modelled to minimize possible errors in surface energy and water fluxes arising from assumed bottom conditions. These conditions are gravitational water drainage and constant temperature taken as the observed multiyear average at $2.5 \mathrm{~m}$ depth. To allow for vertical non-homogeneity, the soil column is divided into five horizons named $\mathrm{H} 1$ to $\mathrm{H} 5$, with depth ranges of $0-0.01,0.01-0.20,0.20-0.70,0.70-$ 1.20 , and $1.20-4.00 \mathrm{~m}$, respectively. The thin $\mathrm{H} 1$ horizon makes it possible to differentiate a surface crust - if any - from the soil proper. Separation of the latter into H2H5 is derived from soil density profiles observed in the two fields. The five-layer soil column is discretized into a total of 194 computation nodes to ensure accurate state variable profiles. These are initialized with soil water content and temperature profiles observed on 1 May 2005, linearly interpolated over the computation domain.

SiSPAT involves a rather large set of input parameters defining soil, vegetation, and surface properties (Table 2). Regarding soil properties, and based on previous experiences with the model for these Sahelian ecosystems (Braud et al., 1997; Braud, 1998), the water retention and conductivity curves for each horizon are parameterized using the van Genuchten (1980) - with the Burdine (1953) condition and the Brooks and Corey (1964) models, respectively. This leads to six hydrodynamic parameters $\left(\theta_{\mathrm{sat}}, \theta_{\mathrm{r}}, K_{\text {sat }}, \beta, h_{g}, n\right)$ for each soil horizon (Table 2). For most model parameters, estimated values or plausible ranges are derived directly either from field observations or from the literature (Table 2). Note that pedotransfer functions are found to be of little help for prior conditioning of soil hydrodynamic properties, as ranges obtained are considerably larger than what is to be expected from the other information sources on these parameters (Velluet, 2014). Four groups of parameters - denoted A to $\mathrm{D}$ in Table 2 - are differentiated, differing in the way they are assigned values in this model implementation, from direct assignment to model calibration on data from two of the 7 years. Definitions of these groups and corresponding parameter assignment methods are detailed in Appendix A. Retained parameter values are shown in Table 2 and discussed in Appendix B together with model evaluation against the whole observation record, which reveals high model capability. Calibration evidences surface crusting at both sites, although much more significantly for the fallow.

The extensive validation of the simulated series (Appendix B) permits derivation, from these entire multivariate series directly, of climatological averages for the water and energy fluxes at both plots for annual to sub-seasonal (running monthly with a view to daily) timescales (Sect. 3). Despite the moderate sample size, sampling-induced uncertainty on estimated means is quite small. Combined with the high model skill, this small statistical uncertainty suggests that robust climatological features can be inferred from the analysis. The significance of these results, as governed by the data and model used and by the way these two sources of information are blended in the study methodology, is discussed in Sect. 4.1. 


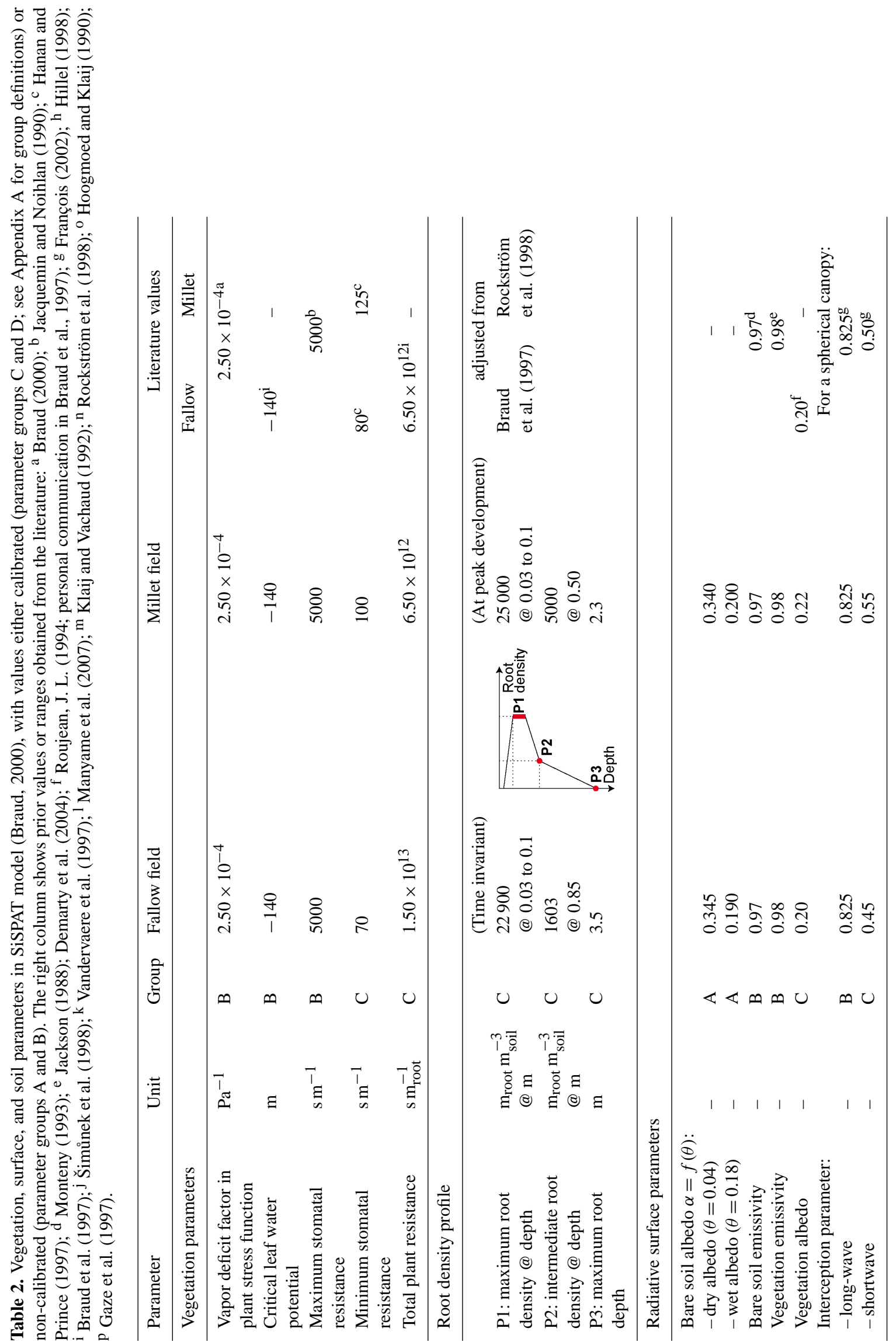




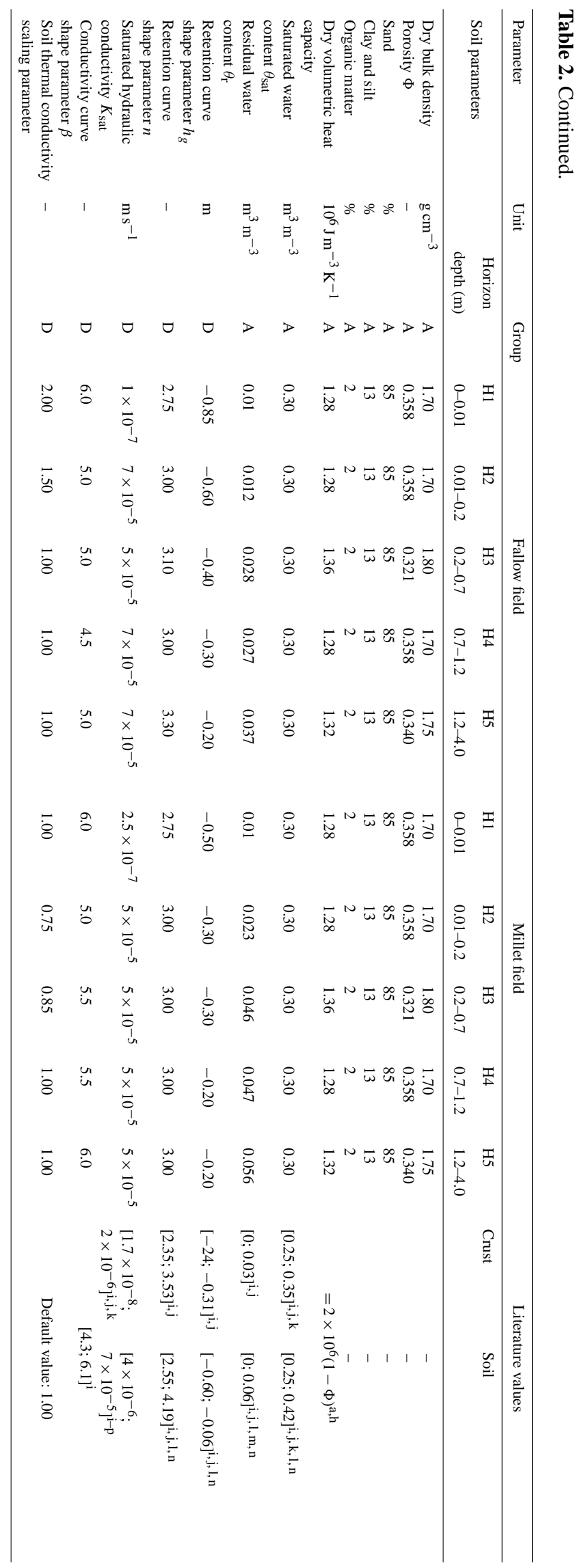



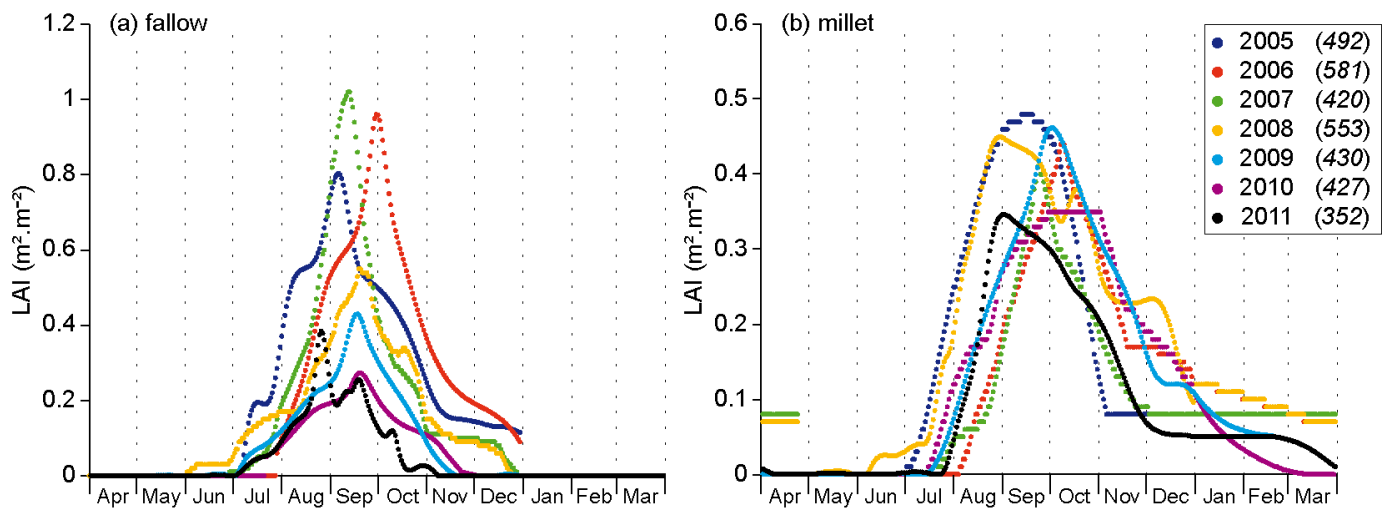

Figure 3. Seasonal course of daily LAI at (a) fallow and (b) millet plots for each growing season of 2005-2011 (in brackets: total rainfall, in millimeters).
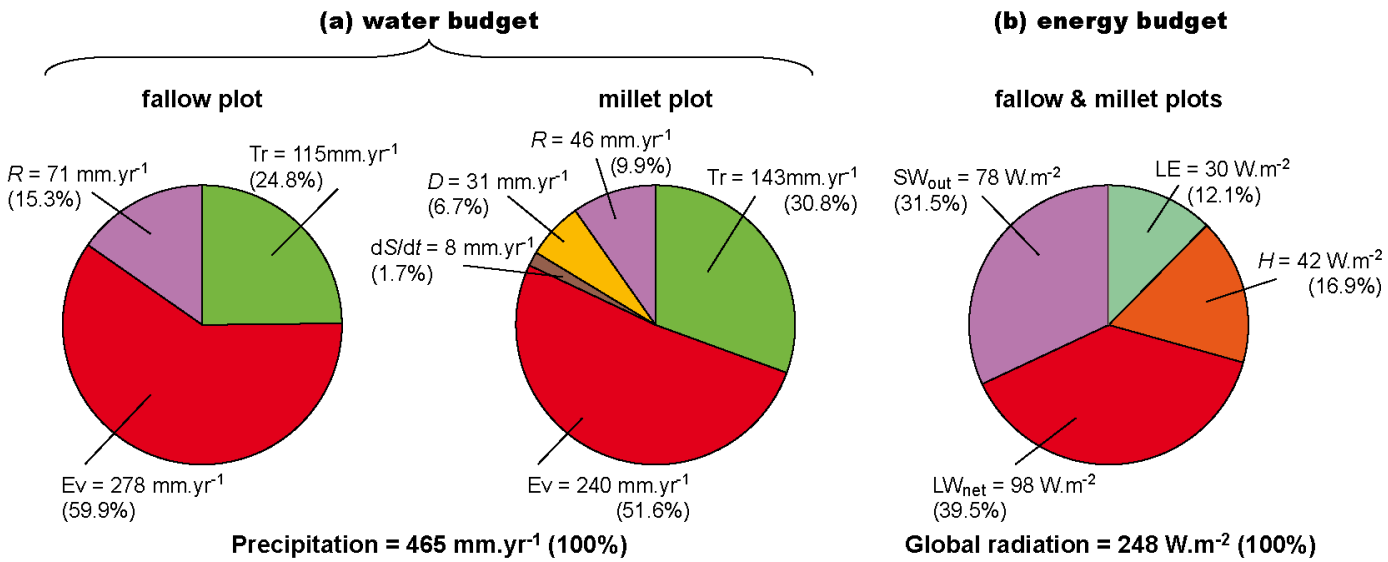

Figure 4. Estimated mean annual (a) water and (b) energy budgets for fallow and millet plots (average of two plots for energy budget, given their similarity at that aggregation scale). Please see Eq. (1) for abbreviations and Fig. 5 for standard estimation errors.

\section{Results: climatology of energy and water cycling at the GAI}

Over the 7-year period, rainfall shows interannual variability in amount and timing in line with that reported for the Wankama catchment over the longer 1992-2006 period (Ramier et al., 2009), suggesting that our study period is representative of the general conditions prevailing in this area. Specifically, annual rainfall (values in legend of Fig. 3) ranges from 350 to $580 \mathrm{~mm} \mathrm{yr}^{-1}$, with a mean and a standard deviation of 465 and $81 \mathrm{~mm} \mathrm{yr}^{-1}$, respectively. Three years have similar, moderately below-average annual rainfall (420-430 $\left.\mathrm{mm} \mathrm{yr}^{-1}\right)$, but differ in the number (38-50), intensity, and time distribution of rain events.

Simulated variables are analyzed in their distribution at annual, semiannual, seasonal, and sub-seasonal scales over the study period, with the aim of estimating an average year for each site from this 7-year sample. Since climatological differences in forcing fluxes (rainfall, incoming short- and longwave radiation) between the two sites are all very small, these specific variables are not duplicated in the following.

\subsection{Annual and semiannual scale}

The two pie charts in Fig. 4a display the distribution of the interannual mean water balance into its component parts for the fallow and the millet systems. It can be seen that (i) direct soil evaporation is the largest component for both systems, and for the fallow particularly ( $60 \%$ of total rainfall against $52 \%$ for the millet field); (ii) canopy transpiration is the second largest in both cases, albeit lower in the fallow $(25 \%)$ than in the millet field (31\%); (iii) these two evaporative components result in quite similar total evapotranspiration for the two systems that largely dominates the water balance ( 85 and $82 \%$, respectively); (iv) runoff ranks next in magnitude for both systems, but is substantially larger for the fallow (15\% against $10 \%$ for the millet field), (v) drainage $(<7 \%)$ and to a lesser extent interannual $0-4 \mathrm{~m}$ soil storage variation $(<2 \%)$ is significant in the millet system only (none in the fallow). Canopy interception/evaporation is found to be nonsignificant in both systems.

Because, at this largest timescale, differences between the two systems are much less substantial for the energy bal- 

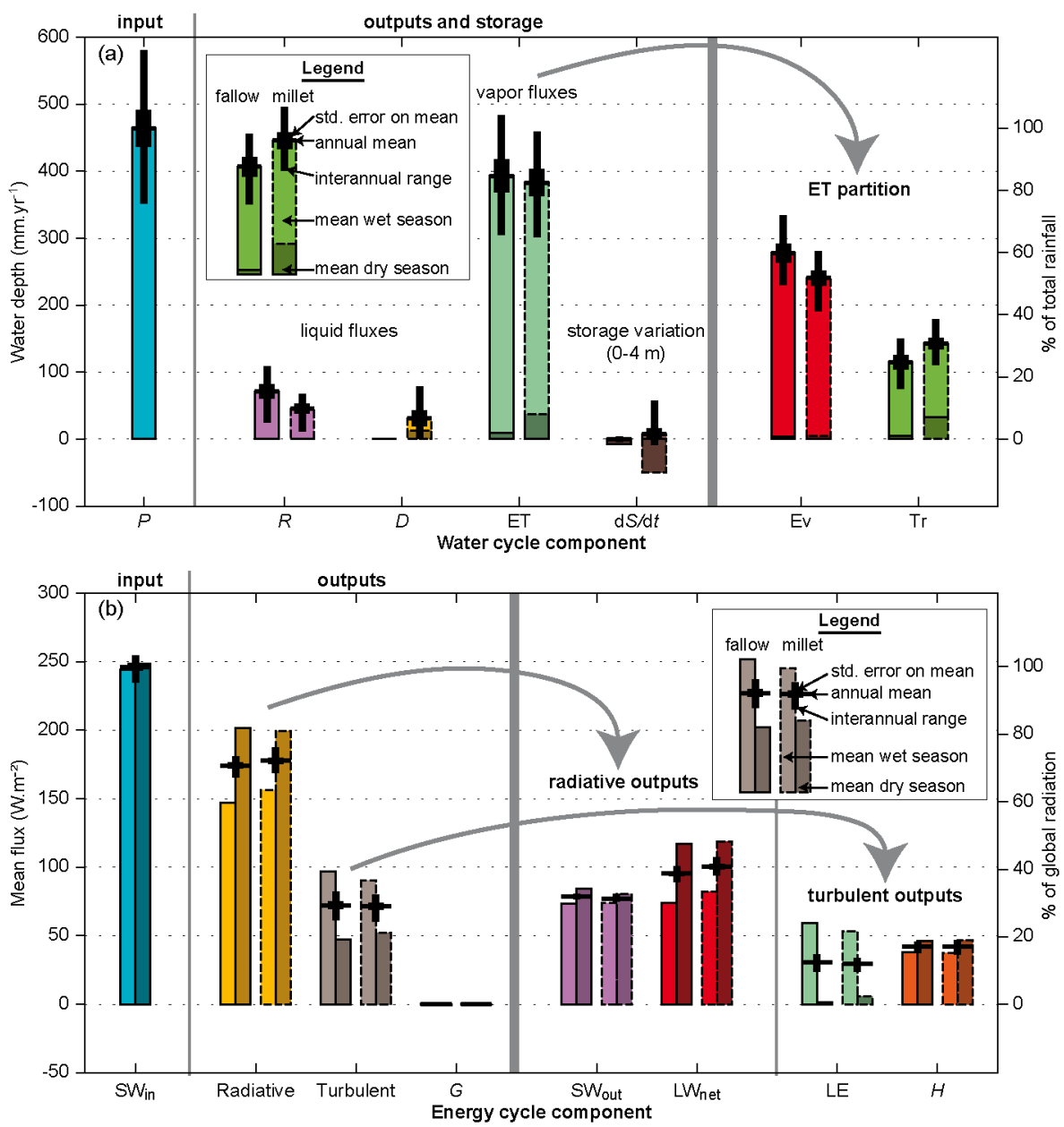

Figure 5. Estimated (a) water and (b) energy budgets at annual and semiannual scales: interannual ranges (black thin bars), annual means with standard estimation errors (black thick bars), and seasons means (light color for wet season, May-October; dark color for dry season, November-April), for the fallow (solid contours) and millet (dashed contours) plots. See Eq. (1) for abbreviations. Note that half-year water depths (color bars in a) are stacked to yield annual values, whereas annual energy fluxes are obtained as the means of half-year mean intensities (b).

ance, a similar decomposition - in this case of total global radiation - is presented only for the average of the two systems (Fig. 4b). It shows that net long-wave radiation is the main component ( $40 \%$ of global radiation), closely followed by reflected solar radiation (32\%). Sensible heat ranks next $(17 \%)$, followed by latent heat $(12 \%)$. Soil heat flux is negligible at this scale of integration. When compared to a globalaveraged continental energy budget (Trenberth et al., 2009), all components are found larger at the study site, including latent heat. Regarding radiative losses, reflected shortwave is closer to net long-wave loss than it is globally. As for turbulent losses, sensible heat is greater than latent heat, contrary to globe averages.

Figure 5 displays in more detail the climatological water and energy balances for both systems, at the annual scale and for two 6-month periods corresponding to the monsoon (May-October) and dry (November-April) seasons. Elemen- tal components are also grouped by type: liquid versus atmospheric vapor fluxes for water (Fig. 5a) and radiative versus turbulent for energy (Fig. 5b). Estimated annual means are shown with standard estimation errors and sample ranges. It can be seen that sampling uncertainty of estimated means is very small for all energy variables (max. standard error of $2.8 \mathrm{~W} \mathrm{~m}^{-2}$ for latent heat flux in the fallow) relative to energy input $\left(248 \mathrm{~W} \mathrm{~m}^{-2}\right)$. Relative to the $465 \mathrm{~mm} \mathrm{yr}^{-1}$ rainfall, standard estimation error is higher for water balance components: up to 14.3 and $21.2 \mathrm{~mm} \mathrm{yr}^{-1}$ for evaporation and total evapotranspiration from the fallow, respectively.

Results suggest that annual-scale differences between ecosystems - even though small for the energy balance are statistically significant for most elemental components. Exceptions are turbulent (latent or sensible) heat fluxes, and also aggregated liquid fluxes. Hence, when switching ecosystems, tradeoffs occur at the annual scale between runoff and 

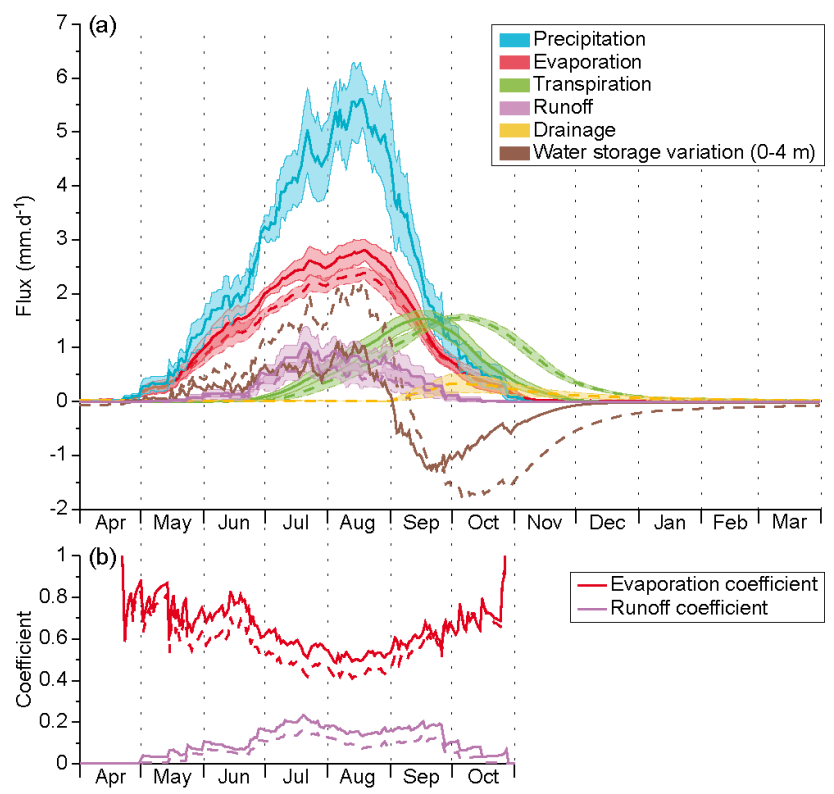

Figure 6. Estimated mean seasonal courses of water cycle components, for fallow (solid lines) and millet (dashed lines) plots: (a) fluxes and rate of storage change in $0-4 \mathrm{~m}$ soil column; (b) ratios of above evaporation and runoff means to rainfall. Means are computed across years and over a 30-day running window. Lightcolored intervals in (a) show a variation of \pm 1 standard estimation error around the estimated mean (not shown for storage change, for legibility).

drainage $\left(\sim 30 \mathrm{~mm} \mathrm{yr}^{-1}\right.$, with more runoff for the fallow and vice versa), between direct soil evaporation and canopy transpiration $\left(\sim 33 \mathrm{~mm} \mathrm{yr}^{-1}\right.$, with more transpiration from the millet field and vice versa), or to a lesser extent between short- and long-wave radiation losses $\left(<6 \mathrm{~W} \mathrm{~m}^{-2}\right.$, with more long-wave for the millet field and vice versa). Stronger yet is the tradeoff $\left(\sim 50 \mathrm{~W} \mathrm{~m}^{-2}\right)$ between radiative and turbulent fluxes when switching seasons (more radiation in dry season and vice versa), particularly between long-wave and latent heat losses. Shortwave radiation and sensible heat are much less impacted, with only 9.3 and $6.6 \mathrm{~W} \mathrm{~m}^{-2}$ variation, respectively. When considering 6-month seasons separately, sensible heat, reflected solar radiation, and wet-season transpiration are still not very significantly different between ecosystems. In contrast, dry-season transpiration is much larger for the millet system with $\sim 23 \%$ of annual total, versus $\sim 4 \%$ for the fallow.

\subsection{Detailed seasonal cycle}

We are interested here in the general pattern of variation of daily variables over an average year, as can be derived from the 7-year sample. Figures $6 a$ and 7 a display the estimated interannual mean seasonal courses of water and energy budget components, respectively. A 30-day running averaging was applied to filter out high-frequency components and ob-
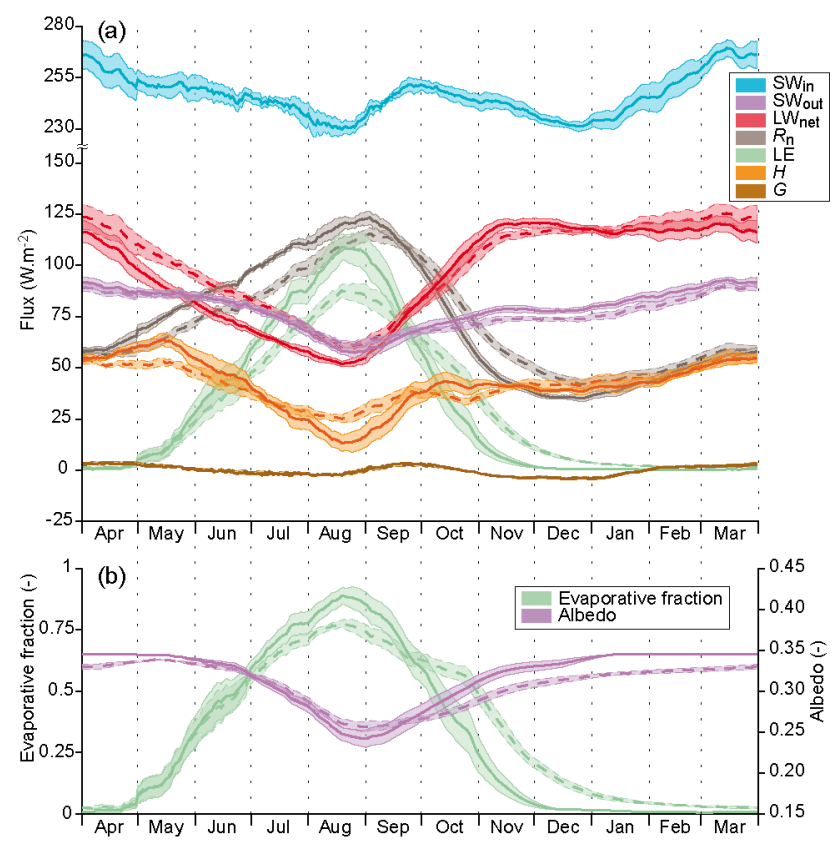

Figure 7. Estimated mean seasonal courses of energy cycle components, for fallow (solid lines) and millet (dashed lines) plots: (a) incoming shortwave and outgoing fluxes; (b) evaporative fraction and albedo. See Eq. (1) for abbreviations and Fig. 6 for further explanation of curves and colored intervals.

tain a more robust estimate of the low-frequency-dominated population's mean seasonal cycle (the value of this filtering is further discussed in Sect. 4.1.3). The sample-induced standard estimation error is shown as a confidence interval for each variable. It can be seen that the sample of years enables deriving interannual mean cycles with low statistical uncertainty, especially for most energy variables. Water cycle variables show somewhat larger relative uncertainties, with the noticeable exception of millet transpiration for which statistical uncertainty is very small $\left(<0.14 \mathrm{~mm} \mathrm{~d}^{-1}\right)$.

\subsubsection{Water}

The rainfall signal displays the slightly skewed bell shape, with a slow rise and sharp tail, that is typical of Sahelian rainfall seasonality (Fig. 6a). It is even strikingly close to the 1990-2007 mean seasonal cycle obtained for a $5^{\circ} \times 5^{\circ}$ window centered on the study site (Lebel and Ali, 2009), including start/end timing, amplitude and timing of the peak $\left(\sim 5.7 \mathrm{~mm} \mathrm{day}^{-1}\right)$ and of the successive phases of monsoon development (plateau in June, secondary peak and break in late July) and recession (plateau of late August), which are characteristic of the central Sahelian monsoon regime.

Overall, both seasonal soil evaporation and runoff follow rather homothetic general courses relative to the rainfall bell, yet smoother for evaporation. Maxima are at 2.8 and $2.4 \mathrm{~mm} \mathrm{day}^{-1}$ for evaporation and 1.1 and $0.8 \mathrm{~mm} \mathrm{day}^{-1}$ for runoff at the fallow and millet sites, respectively (Fig. 6a). 
However, when considering the corresponding ratio to concomitant rainfall (Fig. 6b), a general V-shape is obtained for evaporation, from $\sim 0.8$ at the beginning and the end of the season, down to a low of 0.5 (fallow) or 0.4 (millet) at the monsoon peak. The shape is essentially opposite for the runoff ratio, in the range of $0-0.2$ (lower for the millet field than the fallow), albeit with a double peak: an absolute high in the second half of July (cf. secondary rainfall peak, above, and peak rain intensity in Fig. 2a) and a relative high in late September, separated by a relative low at the monsoon peak.

As transpiration is strongly buffered by the whole soil/vegetation system, it displays a very smooth course (Fig. 6a), lagged relative to rainfall by about 1 month for the fallow and 1.5 months for the millet system, and peaking around $1.5 \mathrm{~mm} \mathrm{day}^{-1}$ (slightly higher for the millet system). The lag in millet field transpiration is to be linked with the late phenological development of this ecosystem (Fig. 3), due in part to shrub management in the mixed crop-shrub farming. It is worth noting, however, that transpiration in the millet field peaks not only well after soil water content (storage inversion in Fig. 6a), but also slightly after LAI, with a growing contribution of the deep root zone (Fig. 8a). This may be traced both to (i) the downward extension of root extraction capacity that continues in that period - with shrub regrowth - in a wet subsoil (Fig. 8b) and (ii) maybe more importantly, the dynamics of the energy budget, with sustained global radiation but vanishing soil evaporation, allowing for higher density of transpiration flux per unit leaf area.

Drainage from the millet plot at $4 \mathrm{~m}$ depth starts later than all other fluxes (around the beginning of September), peaks in October with limited intensity (maximum: $0.3 \mathrm{~mm}_{\text {day }}{ }^{-1}$ ), and recedes slowly over the dry season. Until nearly the end of September, all "consumptive" fluxes (runoff, evaporation, transpiration, but not drainage which has just started) are substantially lower at the millet site than at the fallow, implying much higher storage/lower destorage up to then. This results in much higher soil water content in the millet plot throughout the average year, as illustrated by Fig. $8 \mathrm{~b}$ for the root zone.

\subsubsection{Energy}

Due in particular to intertropical latitude and concomitance of the astronomical summer with the cloudier monsoon season, global radiation shows only limited seasonality (230$275 \mathrm{~W} \mathrm{~m}^{-2}$ range in the average year), with two lows at winter solstice and peak monsoon, an absolute high in March, and a relative high at the end of September (Fig. 7a). Yet seasonality is strong for all consumptive - radiative or turbulent - components of the energy cycle, and is essentially driven directly or indirectly by the single-pulse monsoon and associated water cycle dynamics. Only ground heat flux exhibits a bimodal response, but with small amplitude $\left( \pm 4 \mathrm{~W} \mathrm{~m}^{-2}\right)$. Direct control by water occurs mostly through latent heat, whose dynamics shows among all energy components (i) the
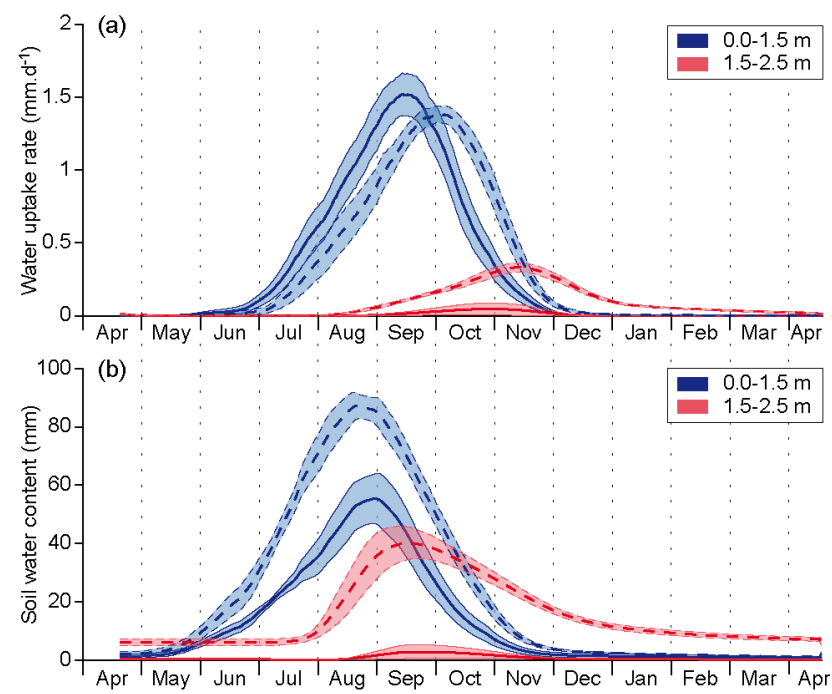

Figure 8. Estimated mean seasonal courses of (a) water uptake by plant roots and (b) soil water storage (above $\theta_{\mathrm{r}}$ ), separately in two active root zone layers (depths in legend) for fallow (solid lines) and millet (dashed lines) plots. See Fig. 6 for further explanation of curves and colored intervals.

largest amplitude, peaking at $\sim 110$ and $90 \mathrm{~W} \mathrm{~m}^{-2}$ for the fallow and millet plots, respectively, and (ii) the shortest duration: latent heat vanishes very quickly in the dry season for the fallow, and $\sim 2$ months later in the millet field. Soil moisture also directly impacts the ground heat flux and albedo via soil thermal conductivity and color, respectively. Indirect water impact is that of vegetation on latent heat and albedo. Combined direct and indirect water effects on albedo (Fig. 7b) result in further reduction of net shortwave seasonality (not shown). Due to the stronger dynamics of soil evaporation compared with canopy transpiration (Fig. 6a), latent heat peaks concomitantly with the former, during transpiration rise, even for the fallow. The time offset for transpiration results in a longer recession of latent heat - especially for the millet field - relative to soil evaporation alone.

As the monsoon sets in, consumption by latent heat of a major part of the net shortwave energy (more than half at monsoon peak, even for the less-consuming millet plot) carves a corresponding hollow in the courses of both net long-wave and sensible heat (Fig. 7a) through the lowering of surface temperature. These hollows are modulated in their amplitude and timing by other atmospheric controls, such as air humidity for net long-wave radiation (making $\mathrm{LW}_{\text {net }}$ start decreasing by early April, i.e., before rainy season onset and peak temperature, thereby offsetting increased solar interception by the atmosphere) or wind regime for sensible heat. Sensible heat and, to a much lesser extent, ground heat reflect a combination of these different forcings, suggesting they are more dependent than all previous fluxes on the interplay between the various land surface forcings and processes. Further illustrating the relative prominence of monsoon pro- 
cesses over incoming solar radiation, net radiation follows a relatively simple course with a long rise (late Decemberearly September) and a short recession.

The energy cycle dynamics is overall sharper and more pronounced for the fallow plot, generally displaying a somewhat earlier timing. For example, like latent heat, net radiation is higher (lower net long-wave) in the fallow until late September, and vice versa until the next monsoon ( $\sim$ end of April). The evaporative fraction (the part of latent heat in total turbulent heat flux, Fig. 7b) reaches around 0.9 in August in the fallow, versus less than 0.7 in the millet field. Differences in sensible heat are shorter in time, with more pronounced extrema (high in May, low in August) for the fallow.

\section{Discussion}

\subsection{Results significance}

\subsubsection{Representativity of study sites and period}

To our knowledge, this study is the first attempt to put forward a climatological view of GAI energy and water fluxes in the Sahel environment. While only two sites are considered in this study, a fallow bush field and a rainfed millet field, these are quite representative of dominant ecosystems in the Sahelian agricultural context. This not only applies to southwestern Niger but also to a very significant part of the whole sub-Saharan Sahelian belt. Variations obviously exist within this huge domain, depending e.g. on geology, monsoon specifics, population, and agricultural practices; however, the first regional flux-site intercomparisons (Merbold et al., 2009; Sjöström et al., 2011, 2013; Lohou et al., 2014) evidenced strong similarities over the Sahelian domain, relative to the other ecoclimatic domains of tropical Africa. Hence, it is believed that the new results obtained at these two sites can serve as a useful reference well beyond the study area.

Previous studies (e.g., Braud, 1998; Verhoef et al., 1999; Miller et al., 2009; Ramier et al., 2009; Saux-Picart et al., 2009a) provided specific experimental and/or modeling results for surface fluxes in such ecosystems over much shorter periods, i.e., at scales ranging from a single event to at most an annual cycle. For instance, Miller et al. (2009) made a detailed field analysis of the surface energy balance at subseasonal to seasonal scales, based on a 1-year record at a Niamey fallow site, i.e., in conditions very similar to ours. However, in light of the 7-year series studied here, it appears that the quite dry observation year $(375 \mathrm{~mm})$ at their site produced substantial flux anomalies, e.g., comparable latent and sensible heat fluxes at the heart of the rainy season. Such results could be misleading if they were considered alone. Conversely, the season analyzed by Ramier et al. (2009) was unusually wet $(580 \mathrm{~mm})$. This underlines the need for multiyear series to derive major features of surface response to variable monsoonal forcing. The unprecedented length of our study period for this region is a step in that direction. Seven years is probably a lower limit for producing robust results. However, it seems a reasonable length in light of the rather small statistical uncertainty on estimated variables. Comparison of rainfall statistics for the 7-year period (interannual mean and variability, seasonal distribution) with longer records for the catchment (Ramier et al., 2009) or for the area (Lebel and Ali, 2009) suggests that our study period is quite representative of current monsoon conditions in the central Sahel. Accounting for non-stationarities in climate or in the hydro-ecosystem (land cover, soil) or for land management variability (e.g., crop/fallow rotation, cultivation practices, animal grazing/manuring) is another challenge facing the long-term observatory in the Wankama catchment (Cappelaere et al., 2009). Now that a seemingly robust model has been developed for these ecosystems, it will be interesting to investigate additional years as more meteorological and phenological forcing data become available.

\subsubsection{Model versus data}

It was suggested in the introduction that the study's objectives could not be met with field data alone. This section further examines the need for and merits of the modeldata integration performed. As mentioned, field data limitations include (i) not all variables of interest being monitored (e.g., evapotranspiration partitioning, runoff, drainage), (ii) substantial, unevenly distributed gap rates (one-fourth to one-third of turbulent fluxes observations missing here after data filtering, depending on variable and site, and 11 to $18 \%$ for other energy fluxes), and (iii) measurement representativity and accuracy issues, including scale discrepancies.

"Black-box" gap-filling techniques do exist, but they boil down to very basic data modeling, with crude hypotheses, which themselves may induce considerable errors and biases. Even when more elaborate modeling is achieved as it is here, observational shortcomings as well as likely statistical biases in deriving a climatology from a heterogeneous series of gap-filled observations severely question the basic gap-filling approach. Using instead the physics-based model simulation for the whole reference series, provided it is constrained by successful calibration/validation with dense and diverse observations through the whole simulation period, better integrates all sources of information into a homogeneous, coherent series. Specifically, it allows to (i) make all available field information work together (across variable types and over time) instead of separately, (ii) constrain them with physical principles for regularization rules to find the best compromise and make the most sense of all these different types of information/knowledge, and (iii) produce output variables at a consistent plot scale, obeying known physics, and as compatible as possible with the whole data set.

Attempting to match a long and diverse set of observations - all high-resolution surface energy fluxes, soil mois- 
ture/temperature profiles - with a rather complex model, could be seen as quite a challenge. Results show that this is feasible for the two ecosystems and the variable forcing conditions (Appendix B), with parameters assigned in part from prior knowledge from the field and the literature, and in part from split-sample calibration/validation ( 2 and 5 years, respectively). This was performed with a heuristic parameter adjustment method, based on expertise with the model, the data, and the field properties and processes (Appendix A). In the authors' judgement, the compromise achieved in integrating the various data and regularization constraints is about the best possible. Some parameter equivalence does exist; however, because of the strong conditioning by the wide range of control variables and simulation conditions, including those for validation, this should not unduly affect the simulated trajectories. In this study, model application is restricted in time to the observation period, which avoids extrapolating to weakly conditioned situations. However, the calibrated model is thought to have the potential for reliable simulations well outside the observed conditions. Regarding unobserved fluxes, the fact that they may often occur separately in time (runoff during rainstorms, evaporation in the early rainy season, transpiration during dry spells and in the early dry season) makes calibration/validation of their main controlling parameters, and hence their simulation, all the more reliable.

These key methodological issues are further discussed in Velluet et al. (2014).

\subsubsection{Timescales of seasonal cycle analysis}

Strictly speaking, because of the 30-day filtering applied to the simulated time series, the mean seasonal cycles produced (Figs. 6-8) pertain to moving monthly quantities. However, the very smooth variations to be expected for the population's mean cycles should imply low sensitivity of the latter to a time resolution below 1 month. Hence, it is believed that the estimated seasonal courses of Figs. 6-8 provide rather good climatological estimates for finer timescales as well, down to daily resolution. For this finest resolution, only the peaks (highs and lows) would be expected to be slightly smoothed out (underestimated maxima, overestimated minima). To get an idea of the possible differences between the population's daily and running monthly mean seasonal cycles, we can simulate their relationship by applying a 30-day filter to the estimated seasonal signals of Figs. 6a and 7a: this reduces the seasonal standard deviation of water cycle variables by only $2 \%$ (for soil evaporation) to $5 \%$ (for runoff), and by $1.5 \%$ (net long-wave or latent heat) to $3 \%$ (sensible heat) for all energy variables but global radiation and ground flux $(\sim 7 \%)$. Note that these figures are quite stable with respect to recursive filter application, suggesting a robust approach. To obtain more rigorous, direct/unbiased estimates for the daily resolution, a record of considerable length would be needed to filter out sampling-induced high-frequency noise and ensure acceptable standard estimation error. To reach at all times the same order of statistical uncertainty as with the estimations presented here, the required length is evaluated to vary from $\sim 15-20$ years for soil water storage or drainage in the millet field to several centuries for rainfall, runoff, ground heat flux, or reflected shortwave (with $>2$ decades for plant transpiration, $>3$ decades for net long-wave radiation, and 6-10 decades for soil evaporation and all turbulent heat fluxes).

Finally, as only the systems' mean behaviors are documented here, variability around climatological means is not reflected. For instance, dry spells commonly occurring within the Sahel monsoon are not shown explicitly but only through their effects on the mean seasonal signals. Thus, it should be kept in mind that, at any timescale (daily to annual), some of the features highlighted by this first-order analysis may not hold at all times, and that they can even turn out to be the opposite under certain circumstances.

\subsection{Insights into some key GAI processes}

This discussion focuses on water cycle processes, as they were shown to also largely condition the other GAI processes in this environment (Sect. 3.2.2).

\subsubsection{Runoff/infiltration, soil storage and drainage}

Runoff values for the two sites are compatible with results from previous field plot studies in the area (e.g., Peugeot et al., 1997; Estèves and Lapetite, 2003). They show high variability, with annual runoff spanning a range of $\sim 120 \%$ of mean for both sites, and annual runoff coefficient ranging 5.6-18.8\% for the fallow and $2.6-13.3 \%$ for the millet plot. High runoff from the fallow is due in particular to a low hydraulic conductivity and high retention in the thin surface horizon (H1), representing the soil crust observed in the field. Lower runoff from the millet field is largely due to the comparatively higher conductivity/lower retention of its own H1 horizon. However, a sharp contrast with the underlying sandy soil (H2-H5 horizons) is also found, confirming that some degree of superficial restriction of infiltration/crusting subsists despite cultivation (Rockström and Valentin, 1997), even if infiltrability is significantly improved.

These differences in rain infiltration capacity between the two plots appear to be one cause for the consistently higher soil water storage obtained for the millet field, but not the only one. The other one - even more important, as hypothesized by Ramier et al. (2009) - appears to be lower evapotranspiration from the millet field, at least until late September (Fig. 7a). On average, these two factors account for, respectively, about one-third and two-thirds of the difference in $0-4 \mathrm{~m}$ soil storage up to that date. Direct soil evaporation dominates in this evapotranspiration contrast; however, both soil evaporation and rainy season plant transpiration are lower in the millet field despite generally higher soil mois- 
ture. Hence, it appears that a combination of factors leads to higher soil water content in the millet field all along the wet season (and hence throughout the whole average year, Fig. 8).

Consequences of this higher water storage are that when the end of the rainy season approaches, drainage can start to occur at the $4 \mathrm{~m}$ depth in the millet field - at least in sufficiently wet years - as well as shrub regrowth that sustains transpiration into the dry season. This is not the case for the fallow. Even though drainage amounts to a modest fraction of the plot water balance, the average $31 \mathrm{~mm} \mathrm{yr}^{-1}$ estimated under the millet field (plus the $8 \mathrm{~mm} \mathrm{yr}^{-1}$ of net soil storage, essentially below the root uptake zone) represents a significant potential recharge source for the unconfined aquifer, given the considerable fraction of land now cropped (e.g., Leblanc et al., 2008). Due to the low water table $(\sim 30-40 \mathrm{~m}$ at the study site; Massuel et al., 2006; Descroix et al., 2012), soil drainage should take years or even decades to actually reach the saturated zone (Ibrahim et al., 2014). Hence, water infiltrated after the extensive clearing of recent decades may in the future contribute to sustain very significantly the current rise in the water table, attributed mainly to enhanced indirect recharge via runoff to surface ponds (Favreau et al., 2009).

\subsubsection{Evapotranspiration and its partitioning}

During most of the year, evapotranspiration appears to be water-limited, with the latent heat flux being tightly connected to variations in soil water and rainfall. Only at the monsoon peak (August-beginning of September) does the evaporative fraction (Fig. 7b) or the ratio to reference evapotranspiration (Allen et al., 1998; not shown) approach 1, suggesting that evapotranspiration becomes then more energylimited. Both ratios peak higher for the fallow, despite lower total soil moisture.

On average over the study period, estimated transpiration amounts to $\sim 32 \%$ of total evapotranspiration at the fallow site and $\sim 40 \%$ at the millet site. This is a little more than that obtained for the same fields by Saux-Picart et al. (2009b) with the SEtHyS_Savannah model $(\sim 27$ and $31 \%$, respectively), but for a 2-year period with higher average rainfall. Simulated millet transpiration is consistent with field estimates during the peak growth season at a nearby site ( $<20 \mathrm{~km}$; Soegaard and Boegh, 1995). Relatively small contributions have been reported for transpiration from the shrub layer in fallows (Brunel et al., 1997; Tuzet et al., 1997). Although no direct continuous observation of this partitioning of evapotranspiration into plant transpiration and soil evaporation is available at the two study sites, the fact that one and only one of these two components is negligible at certain times of year (transpiration in the early rainy season before LAI actually starts; evaporation after the rainy season) enables validation of the other component through total evapotranspiration for those periods.
The increase in transpiration in the late monsoon when soil evaporation declines (Fig. 6a; especially for the millet system where soil moisture is still high) is interpreted partly as reflecting a relaxed competition for energy between the two processes. Note that the climatic water demand, as expressed by reference evapotranspiration, does not rise again after its monsoon low until the winter solstice. A corollary phenomenon, with soil evaporation bursts that appear to depress plant transpiration, is noticeable at smaller timescales, just after rain events. In the following days, transpiration recovers as evaporation declines (also reported by Braud et al., 1997), suggesting that evaporation extinction - for lack of shallow soil moisture - makes energy available for more plant transpiration.

Our results temper the Miller et al. (2009) suggestion that the seasonal course of evapotranspiration is driven primarily by the contribution of plants to atmospheric moisture in this environment. They also temper the hypothesized benefit that plants could draw during a growing season from subsurface moisture accumulated during the previous rainy season: while this does happen in our simulations for the millet field vegetation in the months just after the rainy season $(\sim 7 \%$ of rainfall, on average; Figs. 5a, 6a and 8a) and possibly to a limited extent for moisture carried over from one monsoon season to the next in the 1.5-2.5 m depth range (Fig. 8b), no comparable benefit appears for the fallow in this study.

Partly due to the late wet season/early dry season shrub regrowth in the millet field, the general picture of higher evapotranspiration from a fallow ecosystem than from a millet field (Gash et al., 1997; Ramier et al., 2009) is also somewhat moderated by our results. In this study, this is true on average during most of the rainy season (Fig. 6) - despite generally lower soil moisture - but not in the late SeptemberJanuary period, making annual totals turn out very similar (fallow slightly above). Also, when considering interannual variability, rankings may revert both annually and/or at some periods of the wet season, likely in relation with higher short-timescale variability in transpiration for the fallow. This larger variability can be traced both to the lower and more variable soil storage (Fig. 8b) that makes fallow vegetation more exposed to rainfall shortage, and to the higher LAI variability (Fig. 3) reflecting higher ecosystem sensitivity to environmental conditions (Boulain et al., 2009a) and exposure to external factors such as pasturing.

Finally, our results also suggest that these contrasts in wet season evapotranspiration between the two ecosystems originate at least partly from differences in generation of direct soil evaporation, which is clearly enhanced in the fallow field. Hence, higher rainy season evapotranspiration from the fallow may not (only) be related to plant physiological effects on transpiration, but maybe more importantly to the physics of direct soil-atmosphere exchanges within these two ecosystems (e.g., differences in convective "shield" effect, cf. Tuzet et al., 1997, or in shallow soil properties). 
Whether this conclusion can be generalized requires further analysis.

\section{Conclusions}

The purpose of this work is to build upon a unique, multiyear record of local water and energy observations for two typical plots in southwest Niger in order to propose, for the first time, a climatology of these processes in the Sahel region. The methodology relies on the development of a detailed, physically based GAI column model that is finely calibrated/validated against this important data set. It provides a time- and depth-continuous series of all water and energy variables involved, over a full 7-year period. This includes unobserved variables, most notably direct soil evaporation, plant transpiration, runoff, and drainage. The model, forced with observed meteorology and phenology, is calibrated against 2 years of data and evaluated against the full 7 years, showing very good skill in reproducing the whole observation record. For instance, the model is able to reproduce faithfully the observation of larger evapotranspiration in the fallow than in the millet plot during most of the rainy season despite lower soil moisture. The variety of monsoon conditions encountered and of evaluation variables used - covering the full surface energy balance (short- and long-wave radiation, turbulent fluxes, soil heat flux) and $2.5 \mathrm{~m}$ deep soil moisture and temperature profiles - offers a comprehensive set of constraints that ensures a reliable model trajectory.

The time series simulated for all water and energy variables are analyzed statistically at several timescales: annual and seasonal aggregates, and seasonal cycles of running monthly to daily values. A detailed documentation of climatological mean water and energy cycling, with samplerelated uncertainty, is thus produced. From this analysis, new insights are derived on the interplay between processes that corroborate, refine, or question some ideas proposed so far in the literature. Uncertainty sources other than time sampling are not considered quantitatively in this study, as this requires elaborate assumptions to be made for all possible error sources, which is an upcoming step in this project.

With evapotranspiration/latent heat representing over $80 \%$ of the mean annual water budget and nearly half the energy budget in peak monsoon, the case for studying these two strongly coupled cycles jointly, and for resolving this coupling explicitly, is thus clearly strengthened for the Sahel region. The atmospheric vapor flux is shown to be dominated by direct soil evaporation during most of the monsoon season in the average year. Plant transpiration becomes dominant only in the last part of the wet season (from the second half of September) and continuing into the beginning of the dry season.
Differences between the two land cover types are substantial for most components of the water budget. For instance, differences in estimated annual mean runoff $(\sim 45$ and $\sim 70 \mathrm{~mm} \mathrm{yr}^{-1}$ for the millet and the fallow, respectively) and drainage $\left(\sim 30 \mathrm{~mm} \mathrm{yr}^{-1}\right.$ and nil, respectively) may induce potentially important land use effects on water resources. Nearly all the climatological water fluxes considered are higher in the fallow plot until around the end of September, and over the whole wet season for runoff and soil evaporation; conversely, soil storage, drainage, and dry-season plant transpiration are always larger in the millet field. Differences are somewhat smaller for the energy cycle, with generally more pronounced dynamics in the fallow plot.

These qualitative and quantitative results should prove useful as a reference field information for various purposes such as evaluating and improving land surface models and remote sensing algorithms in the framework of the current ALMIP-2 project ${ }^{2}$ (Boone et al., 2009b). To our knowledge, the study presented here represents one of the most extensive analyses of local field-scale water and energy cycling performed for the Sahelian context to date, associating both a unique data set in length and quality and a very detailed, finely calibrated model. This climatological analysis is currently being extended to sub-seasonal variability around mean behavior, with the aim of providing comprehensive statistical signatures of surface fluxes to serve as reference for land-atmosphere studies. Observations are continuing at the Wankama site to extend model evaluation information, including to other land cover types, and to evaluate effects of land management practices on the water and energy balances (Cappelaere et al., 2009). Finally, as argued strongly in the discussion, it is believed that the unconventional approach used to combine all sources of information available into a homogeneous reference series through extensive model-data integration is the best way to produce the desired climatological characterization. The model properties and qualities also encourages its use for making projections beyond the study conditions (Velluet, 2014).

\footnotetext{
${ }^{2}$ AMMA Land Model Intercomparison Project - Phase 2.
} 


\section{Appendix A: Model parameter assignment methodology}

For groups A and B, assignment is completely independent of model operation. Group A consists of soil parameters derived from field measurements only, either directly, for texture and residual water content $\theta_{\mathrm{r}}$ in each soil horizon, or indirectly, for the horizons' saturated water content $\theta_{\text {sat }}$ and thermal capacity, as well as for dry and wet soil albedos. The $\theta_{\mathrm{r}}$ variable is assigned the lowest water content measured within the horizon (Table 2). With no observations in horizon $\mathrm{H} 1$, the lowest of all measured values $\left(0.01 \mathrm{~m}^{3} \mathrm{~m}^{-3}\right.$, in the fallow's top centimeters) is used instead. The variable $\theta_{\text {sat }}$ is taken uniformly equal to $90 \%$ of average porosity as this parameter displays little heterogeneity or model sensitivity. One reason for low sensitivity is that soil moisture remains far from saturation in this dry sandy environment (except locally within surface crusts during strong rain events). Dry heat capacity is estimated from porosity, for low organic matter (expression in Table 2; Hillel, 1998). Soil albedos are derived from two-way shortwave radiation measurements in periods with no foliage. Parameters in group B (vegetation and soil emissivity, maximum stomatal resistance, vapor deficit factor in plant stress function, critical leaf potential, longwave interception parameter) are assigned from the literature only (Table 2).

Group $\mathrm{C}$ consists of additional vegetation parameters (total plant resistance, minimum stomatal resistance, vegetation albedo, shortwave interception parameter, and root density profile) that are also assigned from values in the literature; however, unlike group B they are slightly adjusted in the final stage of parameter assignment once group D parameters are calibrated. This enables fine tuning for some specific stages of the seasonal cycle (e.g., late monsoon, early dry season), when these parameters are most important. Root profiles are considered invariant for the fallow but seasonally dynamic for the millet system. Finally, group D consists of soil parameters that cannot be ascribed prior values with sufficient accuracy, with respect to model sensitivity to these values, and are thus calibrated within prior ranges (Table 2). These are four hydrodynamic parameters $-K_{\mathrm{sat}}, h_{g}, n, \beta$ - and the soil thermal conductivity scaling parameter, for each horizon. Only two contrasted hydrological years (1 May 200630 April 2008) are used for calibration, the 5 remaining years being devoted to validation. Calibration is performed using a heuristic, stratified approach derived from prior sensitivity investigation, previous experience with the model (Braud, 1998; Boulet et al., 1999; Demarty et al., 2004, 2005), results from similar experiments (e.g., Ridler et al., 2012), and an understanding of the physics of the various processes involved (see e.g., Cappelaere et al., 2009). All observed variables that are sensitive to a subset of parameters being calibrated are used for this purpose, at a half-hourly timestep, with the aim of achieving the best compromise between these variables given their observability (accuracy, representativity). Several regularization rules are applied: (i) parameter values should remain within prior ranges and (ii) spatial variations (with depth and plot) in soil parameters should remain consistent with variations/similarities in observed characteristics. Impacts on the main evaluation variables (all energy fluxes, soil moisture and temperature profiles) are analyzed one parameter at a time, within their range, with the purpose of narrowing the range conservatively. This analysis is repeated for every parameter in subset, and iterated several times until convergence is deemed acceptable. Finally, the aforementioned slight adjustments are made to group $\mathrm{C}$ vegetation parameters.

\section{Appendix B: Model calibration/validation results}

Assigned and calibrated parameter values are listed in Table 2. Dry and wet soil albedo values for the two plots are in good agreement with qualitative field indicators such as soil color and surface roughness. Soil hydrodynamic and thermal parameters in the $\mathrm{H} 2-\mathrm{H} 5$ horizons are consistent with the sandy texture, and exhibit moderate heterogeneity with depth and between sites, especially for the H3-H5 horizons. Among the van Genuchten-Burdine retention parameters and relative to prior ranges, $h_{g}$ is the most variable between horizons $(-0.2$ to $-0.6 \mathrm{~m})$, gradually with depth. Saturated hydraulic conductivity $K_{\text {sat }}$ displays little variability across these horizons with values of $5.10^{-5}-7.10^{-5} \mathrm{~m} \mathrm{~s}^{-1}$, on the upper side of the prescribed range. Most contrasting are the $\mathrm{H} 1$ hydraulic parameters, in accordance with surface crusting observed at the two sites that reduces permeability very substantially. A factor of $1: 700$ is found on $K_{\text {sat }}$ between the surface and the underlying horizons at the fallow site. This factor is lower $(1: 200)$ at the millet site, presumably due to the cultivation effort by the farmer. Similarly, the $\beta$ parameter is found higher for $\mathrm{H} 1$ at both sites, further reducing shallow soil hydraulic conductivity. The $n$ water retention parameter and the thermal conductivity scaling parameter are also different for the $\mathrm{H} 1$ horizon. Finally, values obtained for vegetation resistance parameters agree very well with new experimental results at the fallow (Issoufou et al., 2013) and millet (Issoufou, unpublished data) sites.

Statistics of model skill at half-hourly resolution (root mean square error RMSE, bias, correlation $r$, and NashSutcliffe efficiency - NSE) are shown in Table B1 for the whole 7-year period as well as for the calibration period alone. For both ecosystems, scores are overall very good, relative to the uncertainty that must be expected from these observations, and to what can generally be achieved when modeling these variables. A good balance is reached between the different types of evaluation variables, i.e., surface energy fluxes and soil moisture and temperature profiles. Scores for the two periods are of the same order, suggesting that although calibration uses only 2 years, it is quite robust across variable climatic and environmental conditions, without overfitting to those 2 years' specifics. For many criteria, 
performance over the whole period is even slightly better, due a lower weight of the wettest year (2006) which the model reproduces a little less efficiently.

Overall, model skill appears positively related with the field-estimation precision that can be expected for each variable. Upwelling shortwave radiation is always very well simulated, with RMSEs on the order of $10 \mathrm{~W} \mathrm{~m}^{-2}$ (NSE $\approx 0.99$ ) for any site and period (whole simulation or calibration only). Scores for long-wave radiation are also quite good, albeit with slightly higher RMSEs (in the range of 15$18 \mathrm{~W} \mathrm{~m}^{-2}$, depending on site and period; NSE $\left.\approx 0.93-0.95\right)$. Consequently, RMSEs of net radiation $\left(R_{\mathrm{n}}\right)$ are small, slightly higher for the millet plot $\left(<19 \mathrm{~W} \mathrm{~m}^{-2}\right.$ versus $<15 \mathrm{~W} \mathrm{~m}^{-2}$ for the fallow; NSE $\left.\geq 0.99\right)$, while $R_{\mathrm{n}}$ shows slight positive bias for the fallow $\left(\sim+5 \mathrm{~W} \mathrm{~m}^{-2}\right)$. This positive bias for $R_{\mathrm{n}}$ associated with negative biases for $G$ (at $-5 \mathrm{~cm}$ ), $H$, and LE, illustrates the lack of energy balance closure in the observations, which unduly penalizes model evaluation scores like bias and RMSE. Nonetheless, all these components appear on the whole to follow the high-resolution observations quite well, consistently for both sites and both periods, and better for soil heat (RMSE $\left.\approx 14-18 \mathrm{~W} \mathrm{~m}^{-2}, \mathrm{NSE} \approx 0.92-0.95\right)$ as well as sensible heat $\left(\mathrm{RMSE} \approx 26-29 \mathrm{~W} \mathrm{~m}^{-2}, \mathrm{NSE} \approx 0.87-0.91\right)$ than for latent heat $\left(\mathrm{RMSE} \approx 26-39 \mathrm{~W} \mathrm{~m}^{-2}\right.$, NSE $\approx 0.76-0.78$ ). Turbulent fluxes, especially LE, are obviously the most difficult to measure accurately. In addition, the half-hourly time step is very challenging for modeling as it lies within the scales of turbulence, conferring fluctuations to the fluxes that the model does not resolve. For these reasons, calibration should not overweigh these observations, even though the variables are key with respect to the objectives pursued. The above scores compare very favorably with similar, state-ofthe-art model applications, particularly for this type of climatic and environmental conditions (e.g., Saux-Picart et al., 2009b; Akkermans et al., 2012; Ridler et al., 2012). Biases in these fluxes are low, all below $\sim 5 \mathrm{~W} \mathrm{~m}^{-2}$ for the whole period ( $\leq 6 \%$ of observed standard deviations). At the daily timescale (excluding days with missing data), overall RMSEs across sites fall at or below $9 \mathrm{~W} \mathrm{~m}^{-2}$, and biases at or below $3 \mathrm{~W} \mathrm{~m}^{-2}$, for all energy flux components and all available observations (scatter for $R_{\mathrm{n}}, G, H$, and LE in Fig. B1).

Soil water storage in the different horizons, as estimated from corresponding point measurements (from 0 to $2.5 \mathrm{~m}$ ), is also very well reproduced (Table B1). This is especially true for the upper horizons showing significant dynamics, i.e., $\mathrm{H} 1-\mathrm{H} 3$ for the fallow (NSE $\approx 0.74-0.92$ ) and $\mathrm{H} 1-\mathrm{H} 5$ for the millet field (NSE $\approx 0.72-0.94$ ). The lower horizons $\mathrm{H} 4$ and $\mathrm{H} 5$ of the fallow only show very limited dynamics and can thus hardly be evaluated with this criterion. Although the model seems to infiltrate/store a little too much water in the fallow's H4 horizon (slight positive bias), this is not very significant. The high correlation coefficients, for all periods, sites, and horizons, demonstrate the model's ability to capture the soil water dynamics, in response to the vari-
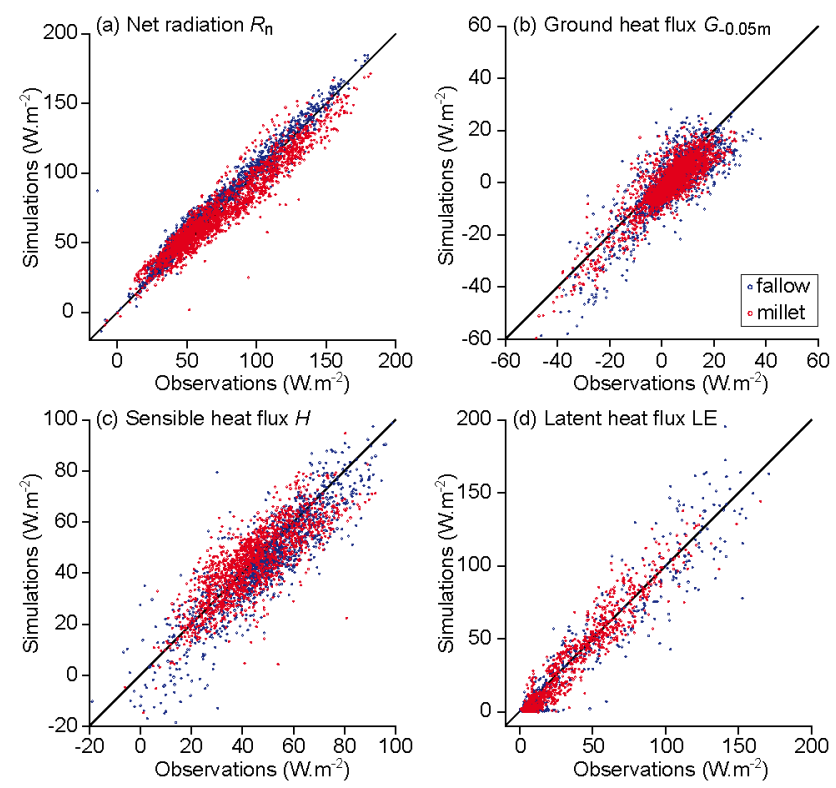

Figure B1. Simulated vs. field-estimated daily energy fluxes of (a) net radiation, (b) ground heat (at $5 \mathrm{~cm}$ depth), (c) sensible heat, and (d) latent heat, for the fallow (blue) and millet (red) plots, over the 2005-2012 study period (only days with no missing data are represented).

ability of external forcings at timescales from event to interannual. This is further illustrated by Fig. B2 for total storage down to $2.5 \mathrm{~m}$ at both sites along the study period. These results, obtained under contrasted hydrologic conditions for two ecosystems responding quite differently, are highly satisfactory.

Scores for soil temperatures show that these are very well reproduced at the millet site (NSE $\approx 0.72-0.96$ ), all the better as depth is less, i.e., as the impact of the bottom boundary assumption is lower and model physics is the main driver. Note that if in absolute terms deviations are higher near the surface (RMSE of $1.3-1.9^{\circ} \mathrm{C}$ at $0.1 \mathrm{~m}$ against $0.6-0.9^{\circ} \mathrm{C}$ below), these have to be related to the much larger variability, making model skill actually turn out better. The same is true also for the fallow plot, albeit with overall lower performance (NSE of 0.48-0.80, RMSE of $2.5-2.8^{\circ} \mathrm{C}$ at $0.1 \mathrm{~m}$, and $0.9-2.2^{\circ} \mathrm{C}$ below). In fact, most of this lack of fit consists of negative bias, which reaches -1.9 to $-2.6^{\circ} \mathrm{C}$ near the surface, and decreases with depth due to tighter constraint by the boundary condition. This is also true, but to a much smaller extent, for the millet plot (bias is -0.4 to $-0.6{ }^{\circ} \mathrm{C}$ near the surface). Hence, the temperature dynamics is actually very well represented, even for the fallow, both in phase (as testified by correlation) and in amplitude, only with constant underestimation. Such a bias was already noticed in similar conditions (model and ecosystems) by Braud (1998), who attributed it to the two-layer radiation conceptualization, when a significant bare soil fraction of the fallow plot actually receives radiation directly with no canopy shielding. 

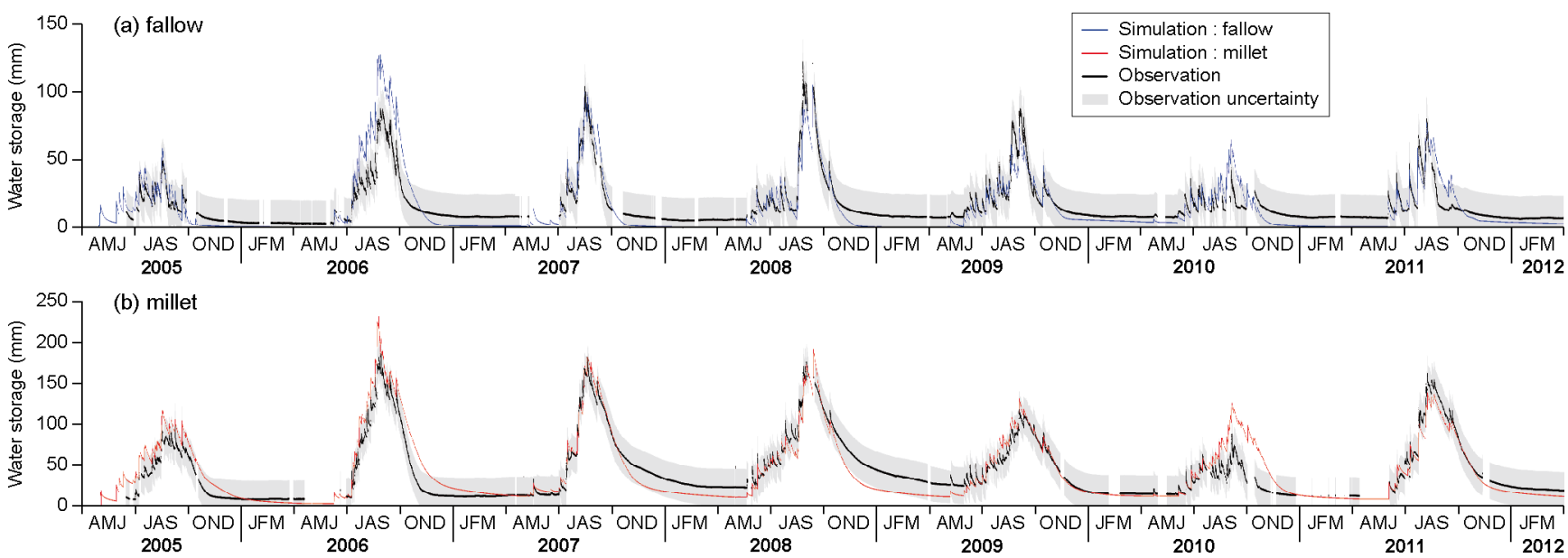

Figure B2. Observed and simulated courses of total water storage in the 0-2.5 m soil layer at (a) fallow and (b) millet plots over 2005-2012 (storage taken above residual water content $\theta_{\mathrm{r}}$ ).

Finally, the high correlation values obtained at half-hourly timescale for both the energy fluxes and the shallow soil temperatures suggest that, in addition to event, seasonal, and interannual dynamics, the phasing of diurnal cycles is also very well represented by the model. 


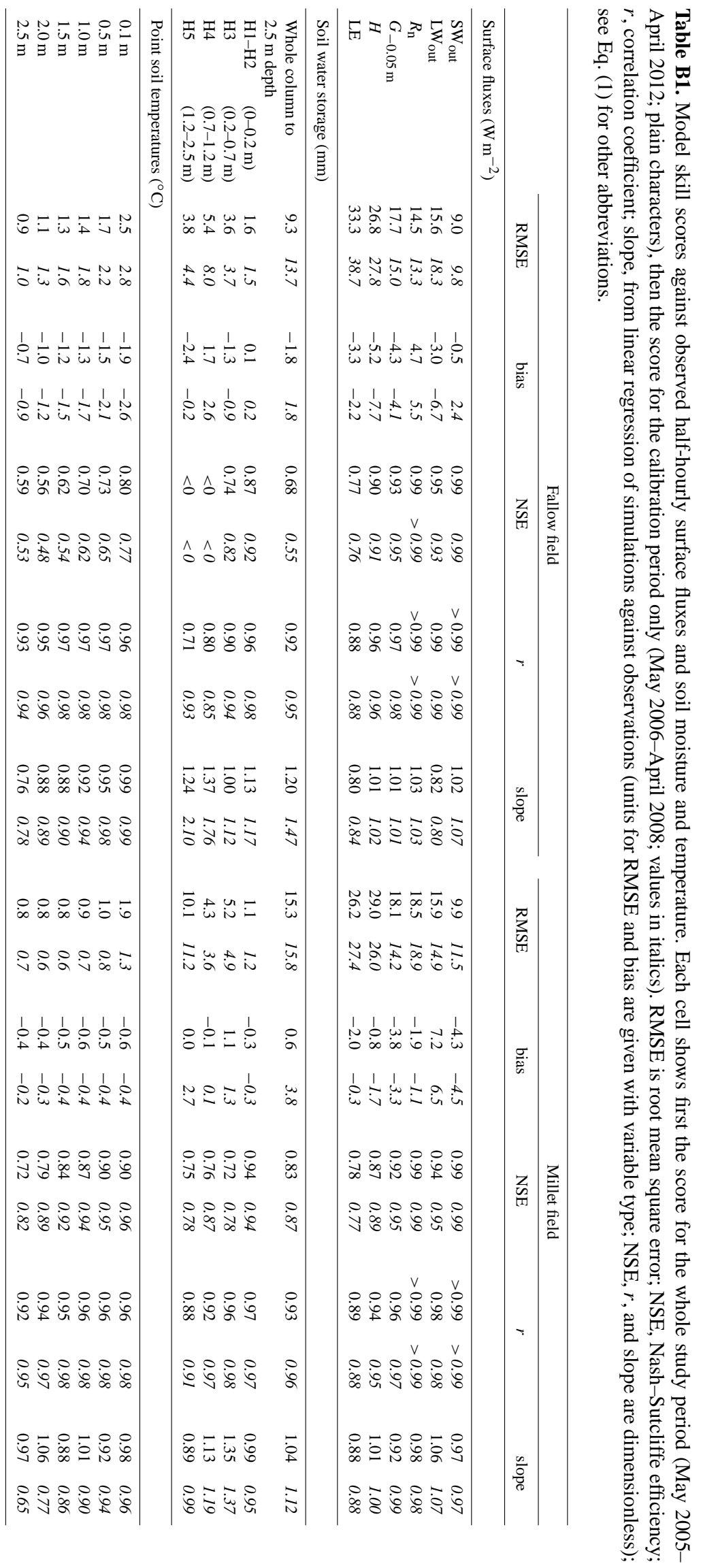


Acknowledgements. The first author's Ph.D. was financed by a student research grant from SIBAGHE Doctoral School at University Montpellier 2 (http://www.sibaghe.univ-montp2.fr). This work was made possible by data from the AMMA-CATCH observing system (http://www.amma-catch.org) in Niger, which is supported by IRD, INSU, and OREME and is a component of the RBV research catchments network (http://rnbv.ipgp.fr). The study also benefited from the partial financial support of ANR (ESCAPE project) and CNES (TOSCA programme). Fruitful discussions with A. Boone, V. Guinot, P. Hiernaux, M. Ibrahim, L. Kergoat, C. Leauthaud, and C. Leduc are gratefully acknowledged. The authors also wish to thank IRD's local representation in Niger (http://www.niger.ird.fr) as well as the residents of Wankama.

Edited by: N. Ursino

\section{References}

Akkermans, T., Lauwaet, D., Demuzere, M., Vogel, G., Nouvellon, Y., Ardö, J., Caquet, B., De Grandcourt, A., Merbold, L., Kutsch, W., and Van Lipzig, N.: Validation and comparison of two soilvegetation-atmosphere transfer models for tropical Africa, J. Geophys. Res., 117, G02013, doi:10.1029/2011jg001802, 2012.

Allen, R. G., Pereira, L. S., Raes, D., and Smith, M.: Crop evapotranspiration: Guidelines for computing crop requirements, FAO, Rome, 300 pp., 1998.

Aubinet, M., Vesala, T., and Papale, D.: Eddy covariance - A practical guide to measurement and data analysis, Springer Atmospheric Sciences, Springer, Dordrecht, 438 pp., 2012.

Boko, M., Niang, I., Nyong, A., Vogel, C., Githeko, A., Medany, M., Osman-Elasha, B., Tabo, R., and Yanda, P.: Africa, in: Climate Change 2007: Impacts, Adaptation and Vulnerability. Contribution of Working Group II to the Fourth Assessment Report of the Intergovernmental Panel on Climate Change, edited by: Parry, M. L., Canziani, O. F., Palutikof, J. P., van der Linden, P. J., and Hanson, C. E., Cambridge University Press, Cambridge, UK, 433-467, 2007.

Boone, A., Decharme, B., Guichard, F., de Rosnay, P., Balsamo, G., Beljaars, A., Chopin, F., Orgeval, T., Polcher, J., Delire, C., Ducharne, A., Gascoin, S., Grippa, M., Jarlan, L., Kergoat, L., Mougin, E., Gusev, Y., Nasonova, O., Harris, P., Taylor, C., Norgaard, A., Sandholt, I., Ottlé, C., Poccard-Leclercq, I., SauxPicart, S., and Xue, Y.: The AMMA Land Surface Model Intercomparison Project (ALMIP), B. Am. Meteorol. Soc., 90, 18651880, doi:10.1175/2009bams2786.1, 2009a.

Boone, A., Getirana, A., Demarty, J., Cappelaere, B., Galle, S., Grippa, M., Lebel, T., Mougin, E., Peugeot, C., and Vischel, T.: The AMMA Land Surface Model Intercomparison Project Phase 2 (ALMIP-2), Gewex News, 19, 9-10, 2009b.

Boulain, N., Cappelaere, B., Ramier, D., Issoufou, H. B. A., Halilou, O., Seghieri, J., Guillemin, F., Oi, M., Gignoux, J., and Timouk, F.: Towards an understanding of coupled physical and biological processes in the cultivated Sahel 2. Vegetation and carbon dynamics, J. Hydrol., 375, 190-203, doi:10.1016/j.jhydrol.2008.11.045, 2009a.

Boulain, N., Cappelaere, B., Seguis, L., Favreau, G., and Gignoux, J.: Water balance and vegetation change in the Sahel: A case study at the watershed scale with an eco-hydrological model, J. Arid Environ., 73, 1125-1135, doi:10.1016/j.jaridenv.2009.05.008, 2009b.

Boulet, G., Kalma, J. D., Braud, I., and Vauclin, M.: An assessment of effective land surface parameterisation in regional-scale water balance studies, J. Hydrol., 217, 225-238, doi:10.1016/s00221694(98)00246-7, 1999.

Braud, I.: Spatial variability of surface properties and estimation of surface fluxes of a savannah, Agr. Forest Meteorol., 89, 15-44, doi:10.1016/s0168-1923(97)00061-0, 1998.

Braud, I.: SiSPAT, a numerical model of water and energy fluxes in the soil-plant-atmosphere continuum - User's manual, LTHE, Grenoble, France, 106 pp., 2000.

Braud, I., Dantas-Antonino, A. C., Vauclin, M., Thony, J. L., and Ruelle, P.: A simple soil-plant-atmosphere transfer model (SiSPAT) development and field verification, J. Hydrol., 166, 213250, 1995.

Braud, I., Bessemoulin, P., Monteny, B., Sicot, M., Vandervaere, J. P., and Vauclin, M.: Unidimensional modelling of a fallow savannah during the HAPEX-Sahel experiment using the SiSPAT model, J. Hydrol., 188-189, 912-945, doi:10.1016/s00221694(96)03177-0, 1997.

Brooks, R. H. and Corey, A. T.: Hydraulic Properties of Porous Media, Hydrology Papers, Colorado State University, Colorado, 1964.

Brunel, J. P., Walker, G. R., Dighton, J. C., and Monteny, B.: Use of stable isotopes of water to determine the origin of water used by the vegetation and to partition evapotranspiration. A case study from HAPEX-Sahel, J. Hydrol., 188-189, 466-481, doi:10.1016/s0022-1694(96)03188-5, 1997.

Burdine, N. T.: Relative permeability calculations from pore-size distribution data, Trans. Am. Inst. Min. Eng., 198, 71-78, 1953.

Cappelaere, B., Descroix, L., Lebel, T., Boulain, N., Ramier, D., Laurent, J. P., Favreau, G., Boubkraoui, S., Boucher, M., Bouzou Moussa, I., Chaffard, V., Hiernaux, P., Issoufou, H. B. A., Le Breton, E., Mamadou, I., Nazoumou, Y., Oi, M., Ottle, C., and Quantin, G.: The AMMA-CATCH experiment in the cultivated Sahelian area of south-west Niger - Investigating water cycle response to a fluctuating climate and changing environment, J. Hydrol., 375, 34-51, doi:10.1016/j.jhydrol.2009.06.021, 2009.

Daamen, C. C.: Two source model of surface fluxes for millet fields in Niger, Agr. Forest Meteorol., 83, 205-230, doi:10.1016/S0168-1923(96)02356-8, 1997.

Demarty, J., Ottlé, C., François, C., Braud, I., and Frangi, J.P.: Effect of aerodynamic resistance modelling on SiSPATRS simulated surface fluxes, Agronomie, 22, 641-650, doi:10.1051/agro:2002052, 2002.

Demarty, J., Ottlé, C., Braud, I., Olioso, A., Frangi, J. P., Bastidas, L. A., and Gupta, H. V.: Using a multiobjective approach to retrieve information on surface properties used in a SVAT model, J. Hydrol., 287, 214-236, doi:10.1016/j.jhydrol.2003.10.003, 2004.

Demarty, J., Ottlé, C., Braud, I., Olioso, A., Frangi, J. P., Gupta, H. V., and Bastidas, L. A.: Constraining a physically based Soil-Vegetation-Atmosphere Transfer model with surface water content and thermal infrared brightness temperature measurements using a multiobjective approach, Water Resour. Res., 41, W01011, doi:10.1029/2004wr003695, 2005.

Descroix, L., Mahe, G., Lebel, T., Favreau, G., Galle, S., Gautier, E., Olivry, J. C., Albergel, J., Amogu, O., Cappelaere, 
B., Dessouassi, R., Diedhiou, A., Le Breton, E., Mamadou, I., and Sighomnou, D.: Spatio-temporal variability of hydrological regimes around the boundaries between Sahelian and Sudanian areas of West Africa: A synthesis, J. Hydrol., 375, 90-102, doi:10.1016/j.jhydrol.2008.12.012, 2009.

Descroix, L., Laurent, J. P., Vauclin, M., Amogu, O., Boubkraoui, S., Ibrahim, B., Galle, S., Cappelaere, B., Bousquet, S., Mamadou, I., Le Breton, E., Lebel, T., Quantin, G., Ramier, D., and Boulain, N.: Experimental evidence of deep infiltration under sandy flats and gullies in the Sahel, Journal of Hydrology, 424-425, 1-15, doi:10.1016/j.jhydrol.2011.11.019, 2012.

Descroix, L., Moussa, I. B., Genthon, P., Sighomnou, D., Mahé, G., Mamadou, I., Vandervaere, J.-P., Gautier, E., Maiga, O. F., Rajot, J.-L., Abdou, M. M., Dessay, N., Ingatan, A., Noma, I., Yéro, K. S., Karambiri, H., Fensholt, R., Albergel, J., and Olivry, J.-C.: Impact of Drought and Land - Use Changes on Surface - Water Quality and Quantity: The Sahelian Paradox, in: Current Perspectives in Contaminant Hydrology and Water Resources Sustainability, chap. 10, edited by: Bradley, P. M., Intech, 243-271, doi:10.5772/54536, 2013.

Estèves, M. and Lapetite, J. M.: A multi-scale approach of runoff generation in a Sahelian gully catchment: a case study in Niger, Catena, 50, 255-271, doi:10.1016/s0341-8162(02)001364, 2003.

Ezzahar, J., Chehbouni, A., Hoedjes, J., Ramier, D., Boulain, N., Boubkraoui, S., Cappelaere, B., Descroix, L., Mougenot, B., and Timouk, F.: Combining scintillometer measurements and an aggregation scheme to estimate area-averaged latent heat flux during the AMMA experiment, J. Hydrol., 375, 217-226, doi:10.1016/j.jhydrol.2009.01.010, 2009.

Favreau, G., Cappelaere, B., Massuel, S., Leblanc, M., Boucher, M., Boulain, N., and Leduc, C.: Land clearing, climate variability, and water resources increase in semiarid southwest Niger: A review, Water Resour. Res., 45, W00A16, doi:10.1029/2007wr006785, 2009.

Federer, C. A.: A soil-plant-atmosphere model for transpiration and availability of soil water, Water Resour. Res., 15, 555-562, doi:10.1029/WR015i003p00555, 1979.

Foken, T.: Micrometeorology, Springer-Verlag, Berlin, 306 pp., 2008.

Foken, T., Wimmer, F., Mauder, M., Thomas, C., and Liebethal, C.: Some aspects of the energy balance closure problem, Atmos. Chem. Phys., 6, 4395-4402, doi:10.5194/acp-6-4395-2006, 2006.

François, C.: The potential of directional radiometric temperatures for monitoring soil and leaf temperature and soil moisture status, Remote Sens. Environ., 80, 122-133, doi:10.1016/s00344257(01)00293-0, 2002.

Gash, J. H. C., Kabat, P., Monteny, B. A., Amadou, M., Bessemoulin, P., Billing, H., Blyth, E. M., deBruin, H. A. R., Elbers, J. A., Friborg, T., Harrison, G., Holwill, C. J., Lloyd, C. R., Lhomme, J. P., Moncrieff, J. B., Puech, D., Soegaard, H., Taupin, J. D., Tuzet, A., and Verhoef, A.: The variability of evaporation during the HAPEX-Sahel Intensive Observation Period, J. Hydrol., 188-189, 385-399, doi:10.1016/s0022-1694(96)03167-8, 1997.

Gaze, S. R., Simmonds, L. P., Brouwer, J., and Bouma, J.: Measurement of surface redistribution of rainfall and modelling its effect on water balance calculations for a millet field on sandy soil in Niger, J. Hydrol., 188-189, 267-284, 1997.

Hanan, N. P. and Prince, S. D.: Stomatal conductance of West-Central supersite vegetation in HAPEX-Sahel: measurements and empirical models, J. Hydrol., 188-189, 536-562, doi:10.1016/s0022-1694(96)03192-7, 1997.

Hillel, D.: Environmental soil physics: Fundamentals, applications, and environmental considerations, Academic Press, San Diego, USA, 771 pp., 1998.

Hoogmoed, W. B. and Klaij, M. C.: Soil management for crop production in the West African Sahel. I. Soil and climate parameters, Soil Till. Res., 16, 85-103, doi:10.1016/0167-1987(90)90023-7, 1990.

Ibrahim, M., Favreau, G., Scanlon, B., Seidel, J.-L., Le Coz, M., Demarty, J., and Cappelaere, B.: Long-term increase in diffuse groundwater recharge following expansion of rainfed cultivation in the Sahel, West Africa, Hydrogeol. J., 22, 1293-1305, doi:10.1007/s10040-014-1143-z, 2014.

Issoufou, H. B.-A., Delzon, S., Laurent, J.-P., Saâdou, M., Mahamane, A., Cappelaere, B., Demarty, J., Rambal, S., and Seghieri, J.: Change in water loss regulation after canopy clearcut of a dominant shrub in Sahelian agrosystems, Guiera senegalensis J. F. Gmel, Trees - Struct. Funct., 27, 1011-1022, doi:10.1007/s00468-013-0852-6, 2013.

Jackson, R. D.: Surface temperature and the surface energy balance, in: Flow and Transport in the Natural Environment: Advances and Applications, edited by: Steffen, W. L. and Denmead, O. J., Springer, Berlin, New York, 133-182, 1988.

Jacquemin, B. and Noilhan, J.: Sensitivity study and validation of a land surface parameterization using the HAPEXMOBILHY data set, Bound.-Lay. Meteorol., 52, 93-134, doi:10.1007/bf00123180, 1990.

Jarvis, P. G.: The Interpretation of the Variations in Leaf Water Potential and Stomatal Conductance Found in Canopies in the Field, Philos. T. Roy. Soc. Lond. B, 273, 593-610, doi:10.1098/rstb.1976.0035, 1976.

Klaij, M. C. and Vachaud, G.: Seasonal water balance of a sandy soil in Niger cropped with pearl millet, based on profile moisture measurements, Agr. Water Manage., 21, 313-330, doi:10.1016/0378-3774(92)90053-y, 1992.

Koster, R. D., Dirmeyer, P. A., Guo, Z., Bonan, G., Chan, E., Cox, P., Gordon, C. T., Kanae, S., Kowalczyk, E., Lawrence, D., Liu, P., Lu, C. H., Malyshev, S., McAvaney, B., Mitchell, K., Mocko, D., Oki, T., Oleson, K., Pitman, A., Sud, Y. C., Taylor, C. M., Verseghy, D., Vasic, R., Xue, Y., and Yamada, T.: Regions of strong coupling between soil moisture and precipitation, Science, 305, 1138-1140, doi:10.1126/science.1100217, 2004.

Lebel, T. and Ali, A.: Recent trends in the Central and Western Sahel rainfall regime (1990-2007), J. Hydrol., 375, 52-64, doi:10.1016/j.jhydrol.2008.11.030, 2009.

Lebel, T., Cappelaere, B., Galle, S., Hanan, N., Kergoat, L., Levis, S., Vieux, B., Descroix, L., Gosset, M., Mougin, E., Peugeot, C., and Seguis, L.: AMMA-CATCH studies in the Sahelian region of West-Africa: An overview, J. Hydrol., 375, 3-13, doi:10.1016/j.jhydrol.2009.03.020, 2009.

Leblanc, M. J., Favreau, G., Massuel, S., Tweed, S. O., Loireau, M., and Cappelaere, B.: Land clearance and hydrological change in the Sahel: SW Niger, Global Planet. Change, 61, 135-150, doi:10.1016/j.gloplacha.2007.08.011, 2008. 
Lloyd, C. R., Bessemoulin, P., Cropley, F. D., Culf, A. D., Dolman, A. J., Elbers, J., Heusinkveld, B., Moncrieff, J. B., Monteny, B., and Verhoef, A.: A comparison of surface fluxes at the HAPEXSahel fallow bush sites, J. Hydrol., 189, 400-425, 1997.

Lohou, F., Kergoat, L., Guichard, F., Boone, A., Cappelaere, B., Cohard, J.-M., Demarty, J., Galle, S., Grippa, M., Peugeot, C., Ramier, D., Taylor, C. M., and Timouk, F.: Surface response to rain events throughout the West African monsoon, Atmos. Chem. Phys., 14, 3883-3898, doi:10.5194/acp-14-3883-2014, 2014.

Manyame, C., Morgan, C. L., Heilman, J. L., Fatondji, D., Gerard, B., and Payne, W. A.: Modeling hydraulic properties of sandy soils of Niger using pedotransfer functions, Geoderma, 141, 407415, doi:10.1016/j.geoderma.2007.07.006, 2007.

Marshall, M., Tu, K., Funk, C., Michaelsen, J., Williams, P., Williams, C., Ardö, J., Boucher, M., Cappelaere, B., de Grandcourt, A., Nickless, A., Nouvellon, Y., Scholes, R., and Kutsch, W.: Improving operational land surface model canopy evapotranspiration in Africa using a direct remote sensing approach, Hydrol. Earth Syst. Sci., 17, 1079-1091, doi:10.5194/hess-17-10792013, 2013.

Massuel, S., Favreau, G., Descloitres, M., Le Troquer, Y., Albouy, Y., and Cappelaere, B.: Deep infiltration through a sandy alluvial fan in semiarid Niger inferred from electrical conductivity survey, vadose zone chemistry and hydrological modelling, Catena, 67, 105-118, doi:10.1016/j.catena.2006.02.009, 2006.

Massuel, S., Cappelaere, B., Favreau, G., Leduc, C., Lebel, T., and Vischel, T.: Integrated surface water-groundwater modelling in the context of increasing water reserves of a Sahelian aquifer, Hydrolog. Sci. J., 56, 1242-1264, doi:10.1080/02626667.2011.609171, 2011.

Mauder, M. and Foken, T.: Documentation and instruction manual of the eddy covariance software package TK2, U. Bayreuth, Abt. Mikrometeorologie, Bayreuth, Germany, 2004.

Merbold, L., Ardö, J., Arneth, A., Scholes, R. J., Nouvellon, Y., de Grandcourt, A., Archibald, S., Bonnefond, J. M., Boulain, N., Brueggemann, N., Bruemmer, C., Cappelaere, B., Ceschia, E., El-Khidir, H. A. M., El-Tahir, B. A., Falk, U., Lloyd, J., Kergoat, L., Le Dantec, V., Mougin, E., Muchinda, M., Mukelabai, M. M., Ramier, D., Roupsard, O., Timouk, F., Veenendaal, E. M., and Kutsch, W. L.: Precipitation as driver of carbon fluxes in 11 African ecosystems, Biogeosciences, 6, 1027-1041, doi:10.5194/bg-6-1027-2009, 2009.

Miller, R. L., Slingo, A., Barnard, J. C., and Kassianov, E.: Seasonal contrast in the surface energy balance of the Sahel, J. Geophys. Res., 114, D00E05, doi:10.1029/2008jd010521, 2009.

Milly, P. C. D.: Moisture and heat transport in hysteretic, inhomogeneous porous media: A matric head-based formulation and a numerical model, Water Resour. Res., 18, 489-498, doi:10.1029/WR018i003p00489, 1982.

Monteny, B. A.: HAPEX-Sahel 1992, Campagne de Mesures Supersite Central Est, ORSTOM, Montpellier, France, p. 230, 1993.

Pellarin, T., Laurent, J. P., Cappelaere, B., Decharme, B., Descroix, L., and Ramier, D.: Hydrological modelling and associated microwave emission of a semi-arid region in South-western Niger, J. Hydrol., 375, 262-272, doi:10.1016/j.jhydrol.2008.12.003, 2009

Peugeot, C., Esteves, M., Galle, S., Rajot, J.-L., and Vandervaere, J. P.: Runoff generation processes: results and analysis of field data collected at the East Central Supersite of the HAPEX-Sahel experiment, J. Hydrol., 188-189, 179-202, doi:10.1016/s00221694(96)03159-9, 1997.

Ramier, D., Boulain, N., Cappelaere, B., Timouk, F., Rabanit, M., Lloyd, C. R., Boubkraoui, S., Metayer, F., Descroix, L., and Wawrzyniak, V.: Towards an understanding of coupled physical and biological processes in the cultivated Sahel - 1. Energy and water, J. Hydrol., 375, 204-216, doi:10.1016/j.jhydrol.2008.12.002, 2009.

Ridler, M. E., Sandholt, I., Butts, M., Lerer, S., Mougin, E., Timouk, F., Kergoat, L., and Madsen, H.: Calibrating a soil-vegetation-atmosphere transfer model with remote sensing estimates of surface temperature and soil surface moisture in a semi arid environment, J. Hydrol., 436-437, 1-12, doi:10.1016/j.jhydrol.2012.01.047, 2012.

Rockström, J. and Valentin, C.: Hillslope dynamics of on-farm generation of surface water flows: The case of rain-fed cultivation of pearl millet on sandy soil in the Sahel, Agr. Water Manage., 33, 183-210, doi:10.1016/s0378-3774(96)01282-6, 1997.

Rockström, J., Jansson, P. E., and Barron, J.: Seasonal rainfall partitioning under runon and runoff conditions on sandy soil in Niger. On-farm measurements and water balance modelling, J. Hydrol. 210, 68-92, doi:10.1016/s0022-1694(98)00176-0, 1998.

Rothfuss, Y., Braud, I., Le Moine, N., Biron, P., Durand, J.L., Vauclin, M., and Bariac, T.: Factors controlling the isotopic partitioning between soil evaporation and plant transpiration: Assessment using a multi-objective calibration of SiSPATIsotope under controlled conditions, J. Hydrol., 442-443, 75-88, doi:10.1016/j.jhydrol.2012.03.041, 2012.

Saux-Picart, S., Ottle, C., Decharme, B., Andre, C., Zribi, M., Perrier, A., Coudert, B., Boulain, N., Cappelaere, B., Descroix, L., and Ramier, D.: Water and energy budgets simulation over the AMMA-Niger super-site spatially constrained with remote sensing data, J. Hydrol., 375, 287-295, doi:10.1016/j.jhydrol.2008.12.023, 2009a.

Saux-Picart, S., Ottle, C., Perrier, A., Decharme, B., Coudert, B., Zribi, M., Boulain, N., Cappelaere, B., and Ramier, D.: SEtHyS_Savannah: A multiple source land surface model applied to Sahelian landscapes, Agricultural and Forest Meteorology, 149, 1421-1432, doi:10.1016/j.agrformet.2009.03.013, 2009b.

Schlenker, W. and Lobell, D. B.: Robust negative impacts of climate change on African agriculture, Environ. Res. Lett., 5, 014010, doi:10.1088/1748-9326/5/1/014010, 2010.

Shin, Y., Mohanty, B. P., and Ines, A. V. M.: Soil hydraulic properties in one-dimensional layered soil profile using layerspecific soil moisture assimilation scheme, Water Resour. Res., 48, W06529, doi:10.1029/2010wr009581, 2012.

Shuttleworth, W. J. and Wallace, J. S.: Evaporation from sparse crops - An energy combination theory, Q. J. Roy. Meteorol. Soc., 111, 839-855, doi:10.1256/smsqj.46909, 1985.

Šimůnek, J., Angulo-Jaramillo, R., Schaap, M. G., Vandervaere, J.P., and van Genuchten, M. T.: Using an inverse method to estimate the hydraulic properties of crusted soils from tension-disc infiltrometer data, Geoderma, 86, 61-81, doi:10.1016/s00167061(98)00035-4, 1998.

Sjöström, M., Ardö, J., Arneth, A., Boulain, N., Cappelaere, B., Eklundh, L., de Grandcourt, A., Kutsch, W. L., Merbold, L., Nouvellon, Y., Scholes, R. J., Schubert, P., Seaquist, J., and Veenendaal, E. M.: Exploring the potential of MODIS EVI for model- 
ing gross primary production across African ecosystems, Remote Sens. Environ., 115, 1081-1089, doi:10.1016/j.rse.2010.12.013, 2011.

Sjöström, M., Zhao, M., Archibald, S., Arneth, A., Cappelaere, B., Falk, U., de Grandcourt, A., Hanan, N., Kergoat, L., Kutsch, W. L., Merbold, L., Mougin, E., Nickless, A., Nouvellon, Y., Scholes, R. J., Veenendaal, E. M., and Ardö, J.: Evaluation of MODIS gross primary productivity for Africa using eddy covariance data, Remote Sens. Environ., 131, 275-286, doi:10.1016/j.rse.2012.12.023, 2013.

Soegaard, H. and Boegh, E.: Estimation of evapotranspiration from a millet crop in the Sahel combining sap flow, leaf-area index and eddy-correlation technique, J. Hydrol., 166, 265-282, doi:10.1016/0022-1694(94)05094-e, 1995.

Taconet, O., Bernard, R., and Vidal-Madjar, D.: Evapotranspiration over an agricultural region using a surface flux/temperature model based on NOAA-AVHRR data, J. Clim. Appl. Meteorol., 25, 284-307, 1986.

Tanguy, M., Baille, A., González-Real, M. M., Lloyd, C., Cappelaere, B., Kergoat, L., and Cohard, J. M.: A new parameterisation scheme of ground heat flux for land surface flux retrieval from remote sensing information, J. Hydrol., 454-455, 113-122, doi:10.1016/j.jhydrol.2012.06.002, 2012.

Taylor, C. M., Gounou, A., Guichard, F., Harris, P. P., Ellis, R. J., Couvreux, F., and De Kauwe, M.: Frequency of Sahelian storm initiation enhanced over mesoscale soil-moisture patterns, Nat. Geosci., 4, 430-433, doi:10.1038/ngeo1173, 2011.

Taylor, C. M., de Jeu, R. A. M., Guichard, F., Harris, P. P., and Dorigo, W. A.: Afternoon rain more likely over drier soils, Nature, 489, 423-426, doi:10.1038/nature11377, 2012.

Timouk, F., Kergoat, L., Mougin, E., Lloyd, C. R., Ceschia, E., Cohard, J. M., de Rosnay, P., Hiernaux, P., Demarez, V., and Taylor, C. M.: Response of surface energy balance to water regime and vegetation development in a Sahelian landscape, J. Hydrol., 375, 178-189, doi:10.1016/j.jhydrol.2009.04.022, 2009.

Trenberth, K. E., Fasullo, J. T., and Kiehl, J.: Earth's global energy budget, B. Am. Meteorol. Soc., 90, 311-323, doi:10.1175/2008BAMS2634.1, 2009.

Tuzet, A., Castell, J. F., Perrier, A., and Zurfluh, O.: Flux heterogeneity and evapotranspiration partitioning in a sparse canopy: the fallow savanna, J. Hydrol., 188-189, 482-493, doi:10.1016/s0022-1694(96)03189-7, 1997.

van Genuchten, M. T.: A Closed-form Equation for Predicting the Hydraulic Conductivity of Unsaturated Soils, Soil Sci. Soc. Am. J., 44, 892-898, doi:10.2136/sssaj1980.03615995004400050002x, 1980.
Vandervaere, J. P., Peugeot, C., Vauclin, M., Angulo Jaramillo, R., and Lebel, T.: Estimating hydraulic conductivity of crusted soils using disc infiltrometers and minitensiometers, J. Hydrol., 188189, 203-223, doi:10.1016/s0022-1694(96)03160-5, 1997.

van Vliet, N., Reenberg, A., and Rasmussen, L. V.: Scientific documentation of crop land changes in the Sahel: A half empty box of knowledge to support policy?, J. Arid Environ., 95, 1-13, doi:10.1016/j.jaridenv.2013.03.010, 2013.

Velluet, C.: Multi-year modelling and analysis of the hydrologic and energetic functioning of two dominant ecosystems in the cultivated Sahel (SW Niger), Ph.D. thesis, University Montpellier 2, Montpellier, France, 2014.

Velluet, C., Cappelaere, B., Demarty, J., Braud, I., et al.: Interactive comment on "Building a field- and model-based climatology of local water and energy cycles in the cultivated Sahel - annual budgets and seasonality" by C. Velluet et al., Hydrol. Earth Syst. Sci. Discuss., 11, C2352-C2353, 2014.

Verhoef, A., Allen, S. J., and Lloyd, C. R.: Seasonal variation of surface energy balance over two Sahelian surfaces, Int. J. Climatol., 19, 1267-1277, doi:10.1002/(sici)10970088(199909)19:11<1267::aid-joc418>3.0.co;2-s, 1999.

Verhoef, A., Ottlé, C., Cappelaere, B., Murray, T., Saux Picart, S., Zribi, A., Maignan, F., Boulain, N., Demarty, J., and Ramier, D.: Spatio-temporal surface soil heat flux estimates from satellite data; results for the AMMA experiment, Fakara supersite, Agr. Forest Meteorol., 154-155, 55-66, doi:10.1016/j.agrformet.2011.08.003, 2012.

Wallace, J. S., Wright, I. R., Stewart, J. B., and Holwill, C. J.: The Sahelian energy balance experiment (SEBEX): ground based measurements and their potential for spatial extrapolation using satellite data, Adv. Space Res., 11, 131-141, 1991.

Weiss, M., Baret, F., Smith, G. J., and Jonckheere, I.: Methods for in situ leaf area index measurement, part II: from gap fraction to leaf area index: retrieval methods and sampling strategies, Agr. Forest Meteorol., 121, 17-53, 2004.

Wolters, D., van Heerwaarden, C. C., de Arellano, J. V. G., Cappelaere, B., and Ramier, D.: Effects of soil moisture gradients on the path and the intensity of a West African squall line, Q. J. Royal Meteorol. Soc., 136, 2162-2175, doi:10.1002/qj.712, 2010. 